\title{
Samuel Zell, the Chicago Tribune, and the Emergence of the S ESOP: Understanding the Tax Advantages and Disadvantages of S ESOPs
}

\author{
MiCHAEL S. KNOLL* \\ I. INTRODUCTION
}

In December 2007, Samuel Zell acquired the Chicago Tribune Company (Tribune) using a little-known type of Employee Stock Ownership Plan (ESOP). In a complicated transaction, which took nearly a year to complete, the Tribune converted from a subchapter $\mathrm{C}$ corporation to a subchapter $S$ corporation, established an ESOP that purchased 100 percent of the company's equity, and sold Zell a call option giving him the right to purchase forty percent of the company's equity. ${ }^{1}$ Less than a year after Zell completed his acquisition of the Tribune, the Tribune filed for bankruptcy, a victim of the recession, declining newspaper advertising revenues, and the Tribune's debt-laden capital structure. ${ }^{2}$

Outside of bankruptcy, ESOPs are rarely in the news. Only when they have a connection to a high-profile corporate bankruptcy — most notably the bankruptcies of United Airlines, Enron, Polaroid, and now the Tribune-do ESOPs grab the headlines. ${ }^{3}$ One reason for the lack of attention paid to ESOPs might be that both liberals and conservatives generally support ESOPs as a way of encouraging an "ownership society." Yet in spite of their low profile, ESOPs have a large presence in the U.S. economy.

According to the National Center for Employee Ownership (NCEO), as of February 2008, there were 9,774 ESOPs with total assets in excess of $\$ 928$ billion. ${ }^{4}$ Those ESOPs covered 11.2 million employees ${ }^{5}$ one out of every

* Theodore K. Warner Professor, University of Pennsylvania Law School, and Professor of Real Estate, the Wharton School, University of Pennsylvania. I thank Tom Brennan, Linda Carlisle, and Steve Freeman for comments and suggestions and Alvin Dong, Ann Davidson, Tara Ewald, and Ben Meltzer for assistance with the research. The author acknowledges the financial support of Employee-Owned $\mathrm{S}$ corporations of America (ESCA). However, this Article represents only the author's views, and not the views of ESCA.

${ }^{1}$ Bill McIntyre, The Tribune Company ESOP, OWNERS AT WORK, Summer 2007, at 8 (OWNERS AT WORK is published by the Ohio Employee Ownership Center at Kent State University).

2 Phil Rosenthal \& Michael Oneal, Tribune Co. Files for Bankruptcy Protection, CHI. Trib. REDEYE EDITION, Dec. 9, 2008, at 8.

${ }^{3}$ See Susan Chandler et al., An ESOP Surely; Zell's Probably; Chicago Billionaire Said to Have Edge as Tribune Choice Nears, CHI. TRIB., Apr. 1, 2007, at Cl.

${ }^{4}$ National Center for Employee OWNership, a Statistical Profile of EMPLOYEE OWNERSHIP (2008), available at http://www.nceo.org/library/eo_stat.html. 
twelve private sector employees in the United States, and roughly half of all employees who own stock in their employer hold their shares through an ESOP. ${ }^{6}$

The majority of ESOPs are sponsored by companies that are taxed under subchapter $\mathrm{C}$ of the Internal Revenue Code (Code). These entities, which are commonly called $\mathrm{C}$ corporations, pay the corporate tax. Keeping with that terminology, ESOPs sponsored by such corporations are called C ESOPs.

Although ESOPs are more than thirty years old, ${ }^{7}$ until 1998 , corporations taxed under subchapter $S$ of the Code could not sponsor ESOPs. ${ }^{8}$ $S$ corporations are corporations that do not pay the corporate tax. ${ }^{9}$ Instead, items of income and expense are passed through an $\mathrm{S}$ corporation to its shareholders. ${ }^{10} \mathrm{~S}$ corporations are subject to a wide range of restrictions, including a limit on the number of shareholders (100), ${ }^{11}$ a prohibition on issuing more than one class of stock, ${ }^{12}$ and restrictions on who can be a shareholder. ${ }^{13}$ Until Congress changed the law in the late 1990's, an ESOP could not own the stock of an S corporation. ${ }^{14}$ In 1996 and 1997, Congress

${ }^{5}$ Id.

${ }^{6}$ Steven F. Freeman, Effects of ESOP Adoption and Employee Ownership: Thirty Years of Research and Experience 2 (Univ. of Pa. Ctr. for Organizational Dynamics, Working Paper No. 07-01, 2007), available at http://www.communitywealth.org/_pdfs/articles-publications/esops/paper-freeman.pdf. The next most popular means for employees to hold employer shares is through a 401(k) plan. Id.

${ }^{7}$ For a brief history of the development of ESOPs, see Corey Rosen, How $S$ Corporation ESOPs Came To Be, in INTRODUCTION TO S CORPORATION ESOPS 1 (Scott Rodrick ed., 2d ed. 2005).

${ }^{8}$ Id. at 5.

${ }^{9}$ The exemption of $\mathrm{S}$ corporations from the corporate income tax is by virtue of I.R.C. $\S 1363(\mathrm{a})(2009)$.

${ }^{10}$ I.R.C. $\$ 1361(\mathrm{~b})(1)(A)(2007)$.

11 Id.

12 I.R.C. $\S 1361(\mathrm{~b})(1)(\mathrm{D})$.

${ }^{13}$ I.R.C. $\S 1361(\mathrm{~b})(1)$. Only individuals, estates, certain trusts, and exemption organizations can hold the shares of an $\mathrm{S}$ corporation. Id.

14 Until 1998, an ESOP was not a permissible shareholder of an S corporation. Prior to 1998 , if an ESOP held shares in an S corporation the corporation would not be eligible to be taxed as an $\mathrm{S}$ corporation and so it would be taxed as a $\mathrm{C}$ corporation. Robert W. Smiley, Jr., \& Gregory K. Brown, Employee Stock Ownership Plans (ESOPs), in THE HANDBOOK OF EMPLOYEE BENEFITS: DESIGN FUNDING AND ADMINISTRATION 733, 796 (Jerry S. Rosenbloom ed., 6th ed. 2005); I.R.C. $§ 409$ (h)(B) (2000) (effective date after December 31, 1997). 
made several changes in the tax law, which opened the way for $S$ corporations to sponsor ESOPs. ${ }^{15}$

Over the last ten years, S ESOPs have flourished. ${ }^{16}$ According to some estimates, S ESOPs account for as much as 40 percent of all ESOPs. ${ }^{17}$ And according to some experts, over the last few years, C ESOP adoptions have dwindled, with most recent ESOP adoptions being S ESOPs (especially 100percent owned S ESOPs). ${ }^{18}$

In spite of their economic impact, S ESOPs were, until recently, largely hidden from public view. That changed in April 2007, when Samuel Zell, the Chicago financier and real estate investor, announced that he had reached a deal to acquire the Tribune for $\$ 8.2$ billion in a transaction using an S ESOP. ${ }^{19}$

The Tribune is a media giant. When the deal was announced, the Tribune owned twenty-three television stations, including stations in New York, Los Angeles, and Chicago; fifteen newspapers, including the Chicago Tribune and the Los Angeles Times; and had 23,000 employees. ${ }^{20}$ In addition, the Tribune owned the Chicago Cubs baseball team and Wrigley Field.21 Because of the size of the Tribune deal and the Tribune's ownership of

15 Among the most important of these acts was the Small Business Job Protection Act of 1996, Pub. L. No. 104-188, which added I.R.C. $\S 1361(\mathrm{c})(6)$, effective for tax years beginning after December 31, 1997. This section allows ESOPs to own shares of $\mathrm{S}$ corporations without disqualifying the corporation's election to be taxed as an $S$ corporation (that section further provides that an ESOP counts as a single shareholder) and the Taxpayer Relief Act of 1997, Pub. L. No. 105-34, which repealed the application of the unrelated business income tax to an employee benefit trust if it held shares in an $S$ corporation.

16 See Corey Rosen, ESOPs in S corporations, in COREY ROSEN \& SCOTT RODRICK, UNDERSTANDING ESOPS 39 (2008). S ESOPs also have their own trade association: Employee-Owned S corporations of America (ESCA).

17 Proposed Synthetic Equity Tax Threatens Future S-Corp ESOPs, OWNERS AT WORK (Ohio Employee Ownership Center, Kent State University), Winter 2007/2008, at 3.

18 That view was expressed by several experts in attendance at the ESOP Roundtable sponsored by the Center for Organizational Dynamics at the University of Pennsylvania on May 3, 2008.

${ }^{19}$ Although press reports regularly describe the acquisition price for the Tribune as $\$ 8.2$ billion, the Tribune has $\$ 13$ billion in outstanding debt, the difference being prior debt that was not retired as part of the Zell deal. See Fran Spielman \& David Roeder, Zell No to State Bid for Wrigley; Trib Chief Not Sold on Maverick Financing Deal, CHI. SUN TIMES, May 13, 2008, at 3.

${ }^{20}$ McIntyre, supra note 1.

21 Ameet Sachdev \& Michael Oneal, Meet the Cubs' $\$ 900$ Million Man, CHI. TRIB., Jan. 23, 2009, at C1. 
several American icons, Zell's Tribune transaction brought S ESOPs into public view. ${ }^{22}$

Press reports contain numerous suggestions that the tax benefits from Zell's innovative transaction allowed Zell to increase his bid for the Tribune over those of his rivals. ${ }^{23}$ Several prominent financial commentators predicted that many acquirers would employ the same structure when acquisition activity next heated up. ${ }^{24}$ The Tribune transaction also caught the eye of legislators. As part of a proposed comprehensive reform of the corporate tax system, Congressman Charles Rangel (D-NY), chairman of the House Ways and Means Committee, has offered a provision to increase taxes on interests held indirectly through an S ESOP (synthetic equity), such as the interest held by Zell. 25

Yet, in spite of the attention now being given to S ESOPs, there has been little in-depth analysis of the tax treatment of S ESOPs. Accordingly, the purpose of this Article is to analyze the tax consequences of using an S ESOP. Specifically, I evaluate whether the use of an S ESOP provides tax advantages (and disadvantages) that are not generally available with other transactional structures. I also quantify those advantages (and disadvantages) when they arise. Finally, I apply those insights to the Zell Tribune transaction and estimate the likely tax savings and the increase in bid price that can be attributed to tax savings from the structure.

22 See, e.g., Theo Francis, ESOP Fables: Employee Control Has Downsides, WALL ST. J., Apr. 3, 2007, at B9; Theo Francis, Tribune Highlights Perils of Employee Ownership, GlOBE \& MAIL, Apr. 2, 2007, at B4; Tami Luhby, ESOP is Key to Making Tribune Deal Work, NEwSDAY, Apr. 3, 2007, at A44; Michael Oneal, Tribune Offers Big Payday or Mayday, CHI. TRIB., Apr. 27, 2007, at C1; Allan Sloan, Tribune Deal Makes Zell Ace of Tax Dodgers, WASH. Post, May 1, 2007, at D2; Louis Uchitelle, Employee Owners Don't Necessarily Have a Say in Management, N.Y. TIMES, Apr. 3, 2007, at C1.

23 Chandler et al, supra note 3; Theo Francis, Tribune Highlights Perils of Employee Ownership, GloBe \& MAIL, Apr. 2, 2007, at B4; Michael Oneal \& Phil Rosenthal, Tribune Bidders Ask For New Data; Burkle, Broad Seek Zell Offer's Details, May Try to Top It, CHI. TRIB., Mar. 26, 2007, at C1; Katharine Q. Seelye \& Richard Siklos, Chicagoan Puts Up $\$ 315$ Million to Win $\$ 8.2$ Billion Tribune Co., N.Y. TIMES, Apr. 3, 2007, at A1.

${ }^{24}$ McIntyre, supra note 1, at 8; Nat'l. Ctr. For Employee Ownership, Coming Things That Never Came, EMPLOYEE OWNERSHIP REP, July-Aug. 2008, at 15. Some commentators argued that Zell's control rights are weaker than in a typical buyout and so other acquires might not follow. McIntyre, supra note 1 , at 8 . Other commentators disputed the claim that Zell lacks sufficient control. Id.

25 Tax Reduction Reform Act, H.R. 3970, 110th Cong. \$ 3701 (2007). 


\section{WHAT IS AN ESOP?}

Broadly speaking, an ESOP is a type of defined contribution employee benefit plan. As with other defined contribution plans-such as 401(k), 403(a), and 403(b) plans - the employer makes contributions on behalf of its employees. ${ }^{26}$ Employees sometimes also contribute. In contrast with defined benefit plans, employees with a defined contribution plan are not provided with a guaranteed benefit, such as a pension for the rest of their lives. ${ }^{27}$ Instead, they are entitled to receive either the actual securities they have in their accounts or the market value of those securities. ${ }^{28}$

With an ESOP, the sponsoring company sets up a trust for the principal purpose of acquiring and holding the sponsor's securities for the benefit of its employees. The ESOP thus provides participants with an ownership interest in their employer. Proponents of employee ownership emphasize the incentive and team-building advantages of paying employees in part with employer stock. ${ }^{29}$ Critics argue that concentrating employees' financial resources in their employer's securities increases their exposure to their employer's fortunes. ${ }^{30}$ That debate, between the advantages of more closely aligned incentives and the disadvantages of increased concentration of investments, ${ }^{31}$ has been the central issue in the debate over ESOPs in particular, and employee ownership in general, for many years. ${ }^{32}$

ESOPs can be used to achieve a range of purposes. The most common use of an ESOP is to purchase the shares of a closely held company from a departing owner. ${ }^{33}$ In such circumstances, an ESOP is a way for the departing owner to cash out, maintain control of the company for a period of

26 BNA TAX MGMT. PORTFOLIOS, No. $814 \S \mathrm{I}(\mathrm{A})(2)(\mathrm{b})(5)$ (2008).

27 BNA TAX MGMT. PORTFOLIOS, No. 814 § I(A)(2) (2008).

28 Corey Rosen, How ESOPs Work, in S CORPORATION ESOPS 7-8 (Scott Rodrick ed., $2 d$ ed. 2005).

${ }^{29}$ See, e.g., Freeman, supra note 6, at 7.

30 Id. at 9.

${ }^{31}$ In the language of finance, increased concentration raises the level of unique (or nonsystematic) risk. Unique risk is risk that can be eliminated through diversification. In contrast, systematic risk is that risk that cannot be eliminated by diversification, but can only be shifted among owners. Systematic risk is compensated for in the market (through a higher retum); unique risk is not compensated. See RICHARD A. BREALEY ET AL., PRINCIPLES OF CORPORATE FINANCE 162 (8th ed. 2006). It is because the market provides no compensation for bearing unique risk that some commentators argue employee stock ownership is a bad idea. Freeman, supra note 6, at 9.

32 For a comprehensive and recent survey of the literature on the costs and benefits of ESOPs, see Freeman, supra note 6.

33 Rosen, supra note 28 , at 9. 
time, and arrange for succession. ${ }^{34}$ ESOPs can also be used to provide employees with stock-based compensation so as to better align their interests with those of the stockholders. Other uses include divesting or acquiring subsidiaries, buying back publicly held shares (especially as a takeover defense), and restructuring benefit plans..$^{35}$

ESOPs are authorized and regulated by the Employee Retirement Income and Security Act of 1974 (ERISA). Among the requirements that an ESOP must satisfy are the following: ${ }^{36}$

(i) the ESOP must be designed to invest primarily in securities of the employer; ${ }^{37}$

(ii) contributions cannot exceed statutory maximums; 38

(iii) individual beneficiaries must be able to vote the shares that have been allocated to their individual accounts; ${ }^{39}$ shares not yet allocated can be voted by the ESOP trustee; 40

(iv) ESOP participants have the right to diversify their accounts once they reach certain age and service benchmarks; ${ }^{41}$

(v) the ESOP must meet certain distribution and vesting requirements; $; 2$

34 Jeffrey Tomich, ESOPs Have One-for-All Appeal, ST. LOUIS POST-DiSPATCH, Oct. 30,2005 , at E1.

35 For discussions of the various reasons why companies establish ESOPs, see Corey Rosen, Things To Do With An ESOP Besides Buying Out the Owner, in THE ESOP READER (Scott Rodrick \& Corey Rosen eds., 4th ed. 2005); Jared Kaplan et al., ESOPs, in BNA TAX MGMT. Portfolios, No. 354 § I(B) (2008).

${ }^{36}$ For a comprehensive discussion of the various provisions that regulate ESOPs, see Kaplan et al., supra note 35.

37 I.R.C. $\$ 409$ (1) (2006).

38 The limit on tax-deductible contributions to defined benefit plans is $25 \%$ of covered compensation. I.R.C. $\S 404(a)(3)$ (A) (Supp. 2008).

${ }^{39}$ I.R.C. $\S 409$ (e) (2006). If directions are not timely received, then the trustee can vote these shares. See Rev. Rul. 95-57, 1995-2 C.B. 62. The employees' right to vote their shares applies only to certain key issues. See Rosen, How ESOPs Work, supra note 28 , at 16 .

40 See Kaplan et al, supra note 35, at $\S \mathrm{II}(\mathrm{B})(2)$.

41 When employees reach age fifty and have ten years of service, the company must give them the option of diversifying twenty-five percent of their account balances or withdrawing that amount. I.R.C. $\S 401(a)(28)(B)(2006)$. At age sixty, employees can have half of their account balances diversified or distributed to them. Id.

42 For discussions of these provisions, see, for example, Kaplan et al., supra note 35, at $\S \mathrm{II}(\mathrm{C})$, and Scott Rodrick, ESOP Distribution and Diversification Rules, in THE ESOP READER 108, 109-11 (Scott Rodrick \& Corey Rosen eds., 3d ed. 2003). 
(vi) the trustee is subject to the general fiduciary duties of ERISA; 43

(vii) if the ESOP borrows money, it is subject to a series of additional restrictions; ${ }^{44}$

(viii) the employee has the right to put the employer's securities back to the employer at its fair market price if there is not a liquid market for the securities; ${ }^{45}$ and

(ix) participation in the ESOP cannot occur on a discriminatory basis. ${ }^{46}$

If the ESOP meets all of the above requirements, then the parties' transactions with the ESOP are taxed according to a specific set of rules that apply to ESOPs. ${ }^{47}$ Those rules are widely considered to be very attractive because they confer various tax benefits on the sponsoring employer and the participants that are not otherwise available. However, before discussing the tax treatment of ESOP transactions, the next Part gives a simple example of a leveraged ESOP.

\section{HOW ESOPS WORK}

The typical ESOP is leveraged. That is to say, it uses borrowed money to finance the purchase of the employer's stock. In a leveraged ESOP, the company establishes a trust and the trust borrows money to fund the purchase of employer stock. ${ }^{48}$ Over time, the employer makes contributions to the plan and the plan uses that money to repay the principal and interest on the ESOP loan. ${ }^{49}$ Shares in a leveraged ESOP are initially held in a "suspense

43 Employee Retirement Income Security Act § 404(a), 29 U.S.C. § 1104(a) (2006).

${ }^{44}$ For a discussion of these provisions, see Kaplan et al., supra note 35 , at $\S$ II(C).

${ }^{45}$ I.R.C. $\$ 409$ (h) (2006).

${ }^{46}$ For a brief summary of the participation rules, see Corey Rosen, Questions and Answers on Operating an ESOP, in THE ESOP READER 120, 120-21 (Scott Rodrick \& Corey Rosen eds., $3 d$ ed. 2003).

47 These rules are set forth in I.R.C. $\S 409$ and the accompanying regulations. See 26 C.F.R. $\S \S 1.409$ (p)-1, 1.409-1T (2006).

48 Typically, the company borrows the money from a lender and relends the money to the ESOP. The proceeds of the loan are used to acquire the employer's stock either from the company or from other shareholders. If the stock is acquired from the company, the company can use the proceeds in its business for any legitimate purpose. If the stock is acquired from investors, they can use the money as they like. The ESOP Association, What is a Leveraged ESOP?, http://www.esopassociation.org/about/about_leveraged.asp (last visited April 22, 2009).

49 BNA TAX MGMT. PortFolios, No. 814 § I(A)(2)(b)(5) (2008). 
account." 50 As the loan is repaid, shares are released into the individual accounts of plan participants. ${ }^{51}$

Consider the following simple example of a leveraged ESOP. E Corp. establishes an ESOP and agrees to sell that ESOP 100 shares of E Corp. at a price of $\$ 10$ per share. The ESOP funds the purchase by borrowing $\$ 1000$ at an interest rate of 10 percent, compounded annually. Upon transfer, the 100 shares are held in a suspense account for the benefit of E Corp.'s covered employees. The terms of the loan call for the loan to be repaid in ten equal annual installments of $\$ 162.75$. At the end of the first year, E Corp. contributes $\$ 162.75$ to the ESOP. The ESOP, in turn, pays that same amount to the lender. Of that $\$ 162.75, \$ 100$ is payment of accrued interest and $\$ 62.75$ is repayment of principal. The principal payment of $\$ 62.75$ reduces the outstanding balance of the ESOP loan by 6.27 percent. Accordingly, 6.27 shares 52 will be released from the suspense account into the accounts of individual ESOP participants. ${ }^{53}$ The contribution from the company to the ESOP, the ESOP's payment of interest and principal, and the number of shares released from the suspense account each year are given in Table 1.

Table 1: A Simple Example of a Leveraged ESOP

\begin{tabular}{|c|c|c|c|c|}
\hline Year & Contribution & Interest & Principal & $\begin{array}{c}\text { Shares } \\
\text { Released }\end{array}$ \\
\hline 1 & $\$ 162.75$ & $\$ 100$ & $\$ 62.75$ & 6.27 \\
\hline 2 & 162.75 & 93.73 & 69.02 & 6.90 \\
\hline 3 & 162.75 & 86.82 & 75.92 & 7.59 \\
\hline 4 & 162.75 & 79.23 & 83.51 & 8.35 \\
\hline 5 & 162.75 & 70.88 & 91.87 & 9.19 \\
\hline 6 & 162.75 & 61.69 & 101.05 & 10.11 \\
\hline 7 & 162.75 & 51.59 & 11.16 & 11.12 \\
\hline 8 & 162.75 & 40.47 & 122.27 & 12.23 \\
\hline 9 & 162.75 & 28.25 & 134.50 & 13.45 \\
\hline 10 & 162.75 & 14.80 & 147.95 & 14.80 \\
\hline Total & $\$ 1627.45$ & $\$ 627.45$ & $\$ 1000.00$ & 100 \\
\hline
\end{tabular}

At the end of year 10, the ESOP loan has been repaid and 100 shares of E Corp. stock are in the ESOP accounts of the individual employees. If $E$

50 ld.

51 The release generally must follow one of two formulae. See Rosen, supra note 46, at 122 . In either case, because of stock price volatility, the market value of the shares released each year will rarely equal the principal repayment on the loan that year.

52 That is 6.27 percent of the 100 shares in the ESOP's suspense account.

53 The example assumes immediate vesting. 
Corp. has not paid any dividends over the prior ten years, then the shares will be the only assets in the ESOP.54 Obviously, the total value of the ESOP accounts will depend upon how much each share of E Corp. is worth. If that stock has appreciated, the accounts, in aggregate, will be worth more than $\$ 1000$; if it has declined, they will be worth less.

\section{A Close LoOK at The TAX Consequences of USING AN S ESOP}

The ESOP literature frequently extols tax benefits as one of the principal advantages of and therefore motivations for using an ESOP. ${ }^{55}$ In order for that claim to have merit, the tax benefits of ESOPs on net-after taking out any disadvantages - must be substantially greater than the tax benefits on net that can be achieved through feasible alternative transactions. The tax consequences of C ESOPs were examined by Myron Scholes and Mark Wolfson in 1990, ${ }^{56}$ several years before Congress authorized S ESOPs. ${ }^{57}$ In this Article, I examine the tax consequences of S ESOPs. ${ }^{58}$ Accordingly, in this Part, I take a close look at the tax advantages and disadvantages of S ESOPs relative to other structures. ${ }^{59}$

\section{A. Tax Advantages: Claims and Responses}

Commentators and ESOP promoters regularly claim that there are substantial tax benefits from using an S ESOP.60 They generally make two claims. First, they claim that the ESOP structure allows the employer to deduct repayment of principal on loans incurred by the ESOP.61 Because contributions to an ESOP are deductible, an employer that establishes a leveraged ESOP - an ESOP that borrows funds to purchase employer securities-can deduct repayment of principal. ${ }^{62}$ In contrast, in other situations-including leveraged buyouts - repayment of loan principal is not deductible. ${ }^{63}$ Second, ESOP proponents regularly claim that the use of an $S$ ESOP allows participants to defer tax on their income received through the ESOP. ${ }^{64}$ Both claims are usually made in a manner that suggests that such benefits are, if not unique to the ESOP structure, sufficiently rare to warrant attention. 65

\section{Deduction of Principal}

Subject to limitations on amount, payments made by an employer to an S ESOP are deductible by the employer. ${ }^{66}$ Because those contributions usually go to pay interest and principal on the ESOP loan, the employer can, in effect, deduct both interest and principal on itS ESOP loans. ${ }^{67}$ The ability

54 The example assumes no diversification of the individual ESOP accounts. 
55 The interested reader should see, e.g., the website of the National Center for Employee Ownership, http://www.nceo.org.

${ }^{56}$ Myron S. Scholes \& Mark A. Wolfson, Employee Stock Ownership Plans and Corporate Restructuring: Myths and Realities, FIN. MGMT., Spring 1990, at 12.

57 Congress authorized S ESOPs in 1996, and the provisions became effective on January 1, 1998. Rosen, supra note 7, at 5 .

58 The method I use to analyze the tax consequences of the S ESOP structure endeavors to make an "apples-to-apples" comparison across all parties. The tax consequences of a transaction cannot be understood by just looking at how one party to a transaction is taxed. In order to evaluate the tax consequences of a transaction, it is important to employ an all-parties perspective. If a tax benefit to one party is offset by a tax detriment to another party, then there is no net benefit to the structure. In such cases, no party will likely be helped or hurt by the tax treatment. Instead, the parties are likely to undo the effect of the tax consequences through the terms of the transaction. It is also important to separate the tax and non-tax consequences of a transaction by holding the non-tax consequences equal across transactions so as to avoid confounding tax and nontax consequences. The method for making accurate tax comparisons was developed by Merton H. Miller \& Myron S. Scholes, Executive Compensation, Taxes and Incentives, in FINANCIAL ECONOMICS ESSAYS IN HONOR OF PAUL COOTNER 179, 190-201 (1982). That method was introduced to the legal literature by Michael S. Knoll, The Tax Efficiency of Stock-Based Compensation, 103 TAX NoTES 203 (2004), and David I. Walker, Is Equity Compensation Tax Advantaged?, 84 B.U. L. REV. 695, 699 (2004). That method has been picked up by various legal scholars and is now part of the regular discourse. See Eric D. Chason, Deferred Compensation Reform: Taxing the Fruit of the Tree in its Proper Season, 67 OHIO ST. L.J. 347, 348 (2006); Chris William Sanchirico, The Tax Advantage to Paying Private Equity Fund Managers with Profit Shares: What Is It? Why Is It Bad?, 75 U. CHI. L. REV. 1071, 1077 (2008); Ethan Yale, Investment Risk and the Tax Benefit of Deferred Compensation, 62 TAX L. REV. (forthcoming 2009), available at http://papers.ssrn.com/sol3/papers.cfm?abstract_id $=1279455$.

59 Some proponents of ESOPs argue that the tax benefits to S ESOPs are less generous than those granted to C ESOPs because the seller of shares to an S ESOP cannot take advantage of I.R.C. $\S 1042$. See, e.g., Corey Rosen, ESOPs in S corporations, in THE ESOP READER 38, 40-41 (Scott Rodrick \& Corey Rosen eds., 3d ed. 2003). Section 1042 allows the seller of shares to an ESOP to defer paying tax on the gain from those shares if all of the following conditions are met: (i) the company is a closely held $\mathrm{C}$ corporation; (ii) the seller held her shares for three years or longer; (iii) after the sale, the ESOP holds 30 percent or more of the employer's stock; and (iv) the seller's reinvest the funds in qualified replacement securities, essentially stocks and bonds of domestic corporations without too much passive income. I.R.C. $\S 1042$ (a)-(c) (2006). If the seller satisfies all of those conditions, then the seller can defer her capital gain tax until she sells the replacement securities. By its own terms, Section 1042 does not apply to sales to S ESOPs. See I.R.C. $§ 1042(c)(1)(A)$ (limiting scope of exclusion to employer securities "issued by a domestic C corporation"). The claim that C ESOP tax benefits are more generous than S ESOP benefits has some merit. The ability to defer tax on the sale if the proceeds are invested in qualified securities is valuable. In the extreme, if the qualified securities are held until death, the seller of shares to the ESOP can permanently avoid the entire tax on the gain from those shares. Moreover, although there are some techniques 
to deduct principal is often described as a major tax benefit available only to employers who adopt an ESOP. ${ }^{68}$

Start with the employer. Returning to the example, the employer deducts the payment it makes each year to the S ESOP on behalf of its participants. Thus, the employer would deduct the amount contained in the column labeled "contribution" each year. That is to say, the employer would deduct $\$ 162.75$ each year for 10 years. For shareholders in the 35 percent tax bracket, the deduction reduces taxes by $\$ 56.96$ each year. Thus, over ten years, the deductions reduce the shareholders' taxes by $\$ 569.61$.

that have traditionally been used to transfer the economic interest from owning an asset without triggering immediate taxation, and so would enable sellers to obtain in essence the tax benefit afforded by Section 1042 without using that provision, such "monetization" techniques have been sharply curtailed by the law. I.R.C. $\S 1259$ (constructing sale rules). Thus, the tax benefit afforded sellers to a C ESOP cannot readily be replicated by sellers who do not meet the requirement of that provision.

${ }^{60}$ Rosen, supra note 46, at 134.

61 Id.

62 Rosen, supra note 28, at 7-8; David Ackerman, Legal Considerations for $S$ corporation ESOPs, in S CORPORATION ESOPS 27, 33-35 (Scott Rodrick ed., 2d ed. 2005); Chandler et al., supra note 3; Ashley M. Heher, Tribune Accepts Buyout Offer From Zell, Plans to Sell Cubs, BuFf. News, Apr. 3, 2007, at B7; Mary Lynn F. Jones, Employee Ownership Plans Offer Risks, Rewards, PRESSTIME, May 2007, at 20; Tami Luhby, ESOP Is Key to Making Tribune Deal Work, NEWSDAY, Apr. 3, 2007, at A44; Thomas S. Mulligan, How Zell's Offer for Tribune Might Work, L.A. TIMES, Mar. 29, 2007, at C1.

${ }^{63}$ A related claim that is sometimes made with respect to S ESOPs is that when the ESOP owns 100 percent of the company's stock that no portion of the company's income is taxable. See, e.g., Editorial, ESOP Expectation and Reality, CRAIN's, Apr. 16, 2007, at 10. 2000.

${ }^{64}$ Karen D. Ng, ESOP-The Misunderstood Plan, 26 S.F. ATT'Y 17, Oct.-Nov.

65 See Rosen, supra note 16 (describing unique tax advantages of S ESOP structure).

66 The maximum amount that employers can generally deduct for contributions to an ESOP is 25 percent of total employee compensation. I.R.C. $\S 404$ (a)(3) (Supp. 2008).

67 With a C ESOP, contributions that go to pay principal on an ESOP loan do not count against the 25 percent limit. I.R.C. $\$ 404(a)(3)(A)$ (Supp. 2008). Instead, for such contributions, there is an additional 25 percent limit for contributions that go to pay principal. I.R.C. $\S 404(a)(9)(A)$ (Supp. 2008). Contributions that go to pay interest on the C corporation's ESOP loan are not limited. I.R.C. $\S 404(a)(9)(B)$. For S ESOPs, there are no increased limits. I.R.C. $\S 404(\mathrm{a})(9)(C)$. Instead, for S ESOPs, contributions that go to pay for principal and/or interest on the ESOP loan count against the general 25 percent limit. I.R.C. § 404(a)(9)(C) (2000).

${ }^{68}$ See Corey Rosen, An Overview of ESOPs, in THE ESOP READER 1, 3 (Scott Rodrick \& Corey Rosen eds., 3d ed. 2003). 
Although interest payments in commercial settings are usually deductible, principal payments are almost never deductible. Specifically, the repayment of principal on a loan incurred in a leveraged buyout is not deductible. Thus, if the employer borrowed the funds itself, then only the interest payments would be deductible. In terms of the example, the employer deducts $\$ 100$ in year 1 and $\$ 627.45$ over ten years. At a tax rate of 35 percent, the interest deductions reduce the borrower's taxes by $\$ 219.61$ over ten years. Thus, over the ten-year loan term, the ESOP loan generates tax savings of $\$ 569.61$, whereas the corporate loan reduces taxes by only $\$ 219.61$. The difference- $\$ 350-$ is one advantage of using an S ESOP. Thus, it is often claimed that a major advantage of using an ESOP is that the principal payments on the ESOP loan are, in effect, deductible. ${ }^{69}$

That argument, however, is wrong. The flaw in that argument was first described by Scholes and Wolfson in 1990 in the context of C ESOPs. ${ }^{70}$ Contributions to C ESOPs, they pointed out, are not unusual in being deductible. ${ }^{71}$ Contributions to other pension plans are also deductible, as are other compensation payments, including straight salary. ${ }^{72}$ With only minor exceptions, none of which is relevant here, ${ }^{73}$ all compensation paid to employees is deductible by the employer. ${ }^{74}$ Moreover, payments made by a corporation to an ESOP-whether a C ESOP or an S ESOP-benefit only the ESOP's participants, and not other equity holders. Thus, contributions that are used to repay principal on an ESOP loan are, in effect, compensation paid to those participants and so are properly deducted by the employer who makes them. ${ }^{75}$

The above argument applies with equal force whether an ESOP is owned by a $\mathrm{C}$ corporation or an S corporation. Of course, an S ESOP might own 100 percent of a company, in which case no one gets the deduction. ${ }^{76}$ More generally, if an S ESOP owns a fraction of the company, say 30 percent, then the holders of the rest of the stock ( 70 percent of shares held outside of the ESOP) will have passed through to them 70 percent of the corporation's net

${ }^{69}$ Scholes \& Wolfson, supra note 56, at 22.

70 Id. at 16.

71 Id.

72 Id.

${ }^{73}$ For example, the $\$ 1$ million limit on executive compensation under I.R.C. $\S 162(\mathrm{~m})(2006)$.

${ }^{74}$ I.R.C. $\S 162(\mathrm{a})(1)(2000)$.

${ }^{75}$ Scholes \& Wolfson, supra note 56 , at 16.

76 The majority of S ESOPs own 100 percent of their sponsoring company. COREY ROSEN, NATL. CTR. FOR EMPLOYEE OWNERSHIP, RETIREMENT SECURTTY AND WEALTH ACCUMULATION IN S ESOP COMPANIES 14 (2005), available at http://esca.us/documents/NCEO_STUDY.pdf. 
income after payment of all expenses, including compensation. Treating cash payments made to an S ESOP as expenses-whether used to repay principal on a loan or otherwise-ensures that the remaining shareholders have apportioned to them their share of the corporation's income, and neither more nor less than that amount. There is nothing special or unusual about the deduction. Indeed, what would be extraordinary would be to deny that deduction.

In effect, the deduction for ESOP contributions ensures that there is only one level of tax with an S ESOP. Although one level of tax is generally better than two, one level of tax is not unique to businesses that use an S ESOP. There are numerous ways to achieve one level of tax. First, one can use a pass-through entity. For example, by organizing a business as a sole proprietorship or by using an S corporation, a partnership, or a limited liability company (LLC), the owners of the business can avoid the corporate tax and subject themselves to only one level of taxation. ${ }^{77}$ In other words, an $S$ corporation without an S ESOP will also avoid a second level of tax. Second, leverage can be used to achieve a single level of taxation when the business is held through a $\mathrm{C}$ corporation. ${ }^{78}$ Because interest is deductible from the income of the corporate payor, whereas dividends and redemptions are not, leverage reduces exposure to the corporate tax. ${ }^{79}$ Many companies have a high debt-to-equity ratio as a means to reduce corporate tax by stripping interest income out from a corporation through interest payments. ${ }^{80}$

It therefore follows that the claim that the ability to deduct principal payments on the ESOP loan is a substantial advantage of establishing an S ESOP is without merit. A company with an S ESOP is subject to one level of taxation and there are numerous structures that subject the income generated by a business to only one level of tax. ${ }^{81}$ That brings us to the second claimed tax benefit from using an S ESOP. ${ }^{82}$

${ }^{77}$ I.R.C. $\$ 11$ (2006) (imposing a tax on corporations).

${ }^{78}$ See I.R.C. $\$ 163(a)$ (making interest deductible).

${ }^{79}$ BREALEY ET AL., supra note 31 , at 472-76.

${ }^{80}$ One advantage of using a pass-through entity rather than debt to provide a single level of taxation is that the pass-through entity ensures one level of tax. The business might not support a capital structure made up almost entirely of debt. There is substantial finance literature that shows that risky and intangible assets cannot support as much debt as less risky and tangible assets. See, e.g., RONALD W. MASULIS, THE DEBT/EQUITY CHOICE 90 (1988), Michael Bradley et al., On the Existence of an Optimal Capital Structure: Theory and Evidence, 39 J. FIN. 857, 873-74 (1984); Michael S. Knoll, Taxing Prometheus: How the Corporate Interest Deduction Discourages Innovation and RiskTaking, 48 VILL. L. REV. 1461, 1491-94, 1495 (1993).

${ }^{81}$ Some proponents of S ESOPs claim that the tax benefits afforded S ESOPs are less generous than those afforded C ESOPs because dividends paid to a C ESOP are deductible by the payor provided that the dividends are either: (1) paid in cash; (2) 


\section{Deferral of Income}

From the perspective of the participants, an S ESOP is an example of a qualified account. The beneficiary of a qualified account is not taxed on contributions made to that account; ${ }^{83}$ she is also not taxed on the contribution or investment gains and losses during the life of the account; she is, however, taxed at ordinary income tax rates on the value of the assets withdrawn from her account. ${ }^{84}$ As a result, because S ESOPs are qualified accounts, participants can defer tax on their account balances as long as they continue to hold those assets through the S ESOP. However, when participants withdraw assets from their S ESOP accounts, they pay taxes at ordinary income tax rates, not at capital gains rates. The deferrals of tax on the contribution, appreciation, and dividends are widely acknowledged to be tax advantages from using an S ESOP. ${ }^{85}$

The deferral of tax on income earned through an S ESOP is an attractive feature of using an S ESOP, but it is not unique to S ESOPs. An ESOP is an example of a qualified account. Taxpayers with qualified accounts can deduct their contributions to such accounts; when they make withdrawals from their accounts they include the amounts withdrawn in income at

reinvested in employer securities; or (3) used to repay an ESOP loan. Rosen, supra note 7, at 3; I.R.C. $\S 404(\mathrm{k})$ (2006). Because dividends, including dividends paid to S ESOPs, are not deductible, the treatment of C ESOPs is said to be more favorable than the treatment of S ESOPs. Rosen, supra note 7, at 3. That claim is questionable. The reason why is that the $\S 404(a)(9)$ deduction for dividends paid to an ESOP offsets what would otherwise be corporate level tax on the income that is used to pay the dividend. Ackerman, supra note 62, at 31 . C corporations are subject to two levels of tax and the effect of the deduction is to reduce the tax on such income to one level of tax that is collected when the individual withdraws the funds. Id. That is the same treatment as occurs with an S ESOP without the deduction. If there was a deduction for dividends paid to an ESOP by an S corporation, then that deduction would offset other income and provide even better treatment. For example, if the deduction were allocated to the ESOP participant, then such dividend in effect would forever escape tax. Alternatively, if it were allocated to other owners, then they would escape tax on part of their income.

82 Moreover, because there are no tax consequences to parties other than the participants from the decision to use an ESOP-that is true for both S and C ESOPs (except for the Section 1042 deferral granted to some sellers to C ESOPs)-the tax consequences of the decision to use an S ESOP can be ascertained by looking solely at the participants.

${ }^{83}$ If the contribution is made by the beneficiary out of assets that either will be taxed or already have been taxed, such as with cash contributions into an individual retirement account, then the contribution is deductible. See I.R.C. §219(a) (granting individual taxpayers deductions for their qualified retirement contributions).

${ }^{84}$ I.R.C. § 402(a) (2006).

${ }^{85}$ See, e.g., Ackerman, supra note 62 , at 34. 
ordinary rates. ${ }^{86}$ Also, the limits on qualified accounts are for the total amount contributed to all accounts; the limits are not separate for each type of account. ${ }^{87}$ Moreover, the limit, 25 percent of income, ${ }^{88}$ is generally more than most employees contribute, ${ }^{89}$ and so for most employees the limit is not binding. Thus, for most employers, an ESOP is a substitute for other qualified accounts.

\section{B. Tax Disadvantages: An Old Claim, a Response, and a New Claim}

In this section, I discuss two possible disadvantages from using an $S$ ESOP. The first-which has been pointed out by others-is questionable; the second-which to my knowledge has not been recognized previouslyexists and can arise frequently.

\section{A Higher Tax Rate on Gains}

Commentators sometimes claim that the higher ordinary income tax rate that applies to withdrawals from an ESOP is a disadvantage of investing through an ESOP. ${ }^{90}$ The argument goes as follows: when holding the stock directly would produce long-term capital gain, then the higher ordinary income tax rate paid on that income is a tax disadvantage of using an ESOP. ${ }^{91}$

That simple and intuitive argument, however, is mistaken because it is incomplete. In order to be taxed at long-term capital gains rates on the appreciation in the stock, the stock must be held by the employee directly and not in a qualified account. ${ }^{92}$ That, in turn, requires that the employer pay the employee a salary and the employee purchase the stock. ${ }^{93}$ In that case,

86 Rosen, supra note 28 , at 20.

${ }^{87}$ I.R.C. $\S 404(\mathrm{a})(3)$ (A) (2006).

$88 \mathrm{Id}$.

${ }^{89}$ See Freeman, supra note 6, at 6; ROSEN, RETIREMENT SECURTY, supra note 76, at 5 ("Typical U.S. company contribution plans ... fall in the range of $2 \%$ to $3 \%$ of eligible pay.").

90 See Rosen, supra note 68, at 12.

91 Although I assume throughout this Article in making my calculations that S ESOP participants would be taxed at 35 percent-the top ordinary rate-many S ESOP participants are likely taxed at lower rates. See I.R.C. §§ 401(a)(14), 409(a)(1), 414(q) (2006).

92 Withdrawals from qualified accounts, of which ESOPs are a species, are taxed at ordinary income tax rates. See I.R.C. $\$ 1042$.

93 The stock, then, is a capital asset. See I.R.C. $\S 1221$. Its sale thus produces a capital gain, or loss. I.R.C. $\S 1222$. 
the employee will have taxable income when paid. In contrast, with an ESOP, the employee does not have taxable income when the contributions are made. ${ }^{94}$ Instead, the participant is taxed only when funds are withdrawn from the account..$^{95}$ As is well-known in the tax literature, the effect of deferring tax on a sum is equivalent to exempting the return on that sum from tax until the end of the deferral period. ${ }^{96}$ Thus, the effect of investing through an ESOP - or another qualified account-is to exempt the return on the assets from taxation for as long as they are in the ESOP. From an economic standpoint, the return on those assets while held through the ESOP is not taxed at 35 percent upon withdrawal, but is effectively untaxed. Exemption is obviously more attractive than being subject to tax (albeit deferred) at a 15 percent tax rate.

\section{Borrowing Without an Interest Deduction}

As described above, an ESOP is an attractive saving vehicle because it defers taxation on the funds held through the ESOP. With an ESOP, taxation of the beneficiary on both the contribution and the return on that contribution are deferred until the beneficiary withdraws the funds. The effect of such deferral is the economic equivalent of taxing beneficiaries on their employers' contributions at ordinary income tax rates when earned and exempting the return on those contributions from tax for as long as those amounts are held in ESOP accounts. That equivalence also implies that the borrower, in effect, loses the interest deduction when borrowing through an ESOP.

Viewing the ESOP loan from the employee's perspective, the employer has agreed to make cash contributions to an ESOP for the employee's benefit. The employee, rather than waiting to receive the employer's contributions before acquiring the employer's stock, borrows through the ESOP and purchases the stock right away. The employers' subsequent contributions, instead of going to purchase shares of the employers' stock, pay principal and interest on the ESOP loan. Because the appreciation on the balance in an ESOP account is effectively untaxed, that exemption applies to

94 In both instances, the employer has a deduction when the contribution is made so there is no employer side difference.

95 Rosen, supra note 68, at 14-15.

96 See E. Cary Brown, Business-Income Taxation and Investment Incentives, in INCOME, EMPLOYMENT AND PUBLIC POLICY: ESSAYS IN HONOR OF ALVIN H. HASEN 300, 302-14 (1948), reprinted in AM. ECON. ASS'N, READINGS IN THE ECONOMICS OF TAXATION 525-37 (Richard A. Musgrave \& Carl S. Shoup eds., 1959); William O. Andrews, A Consumption-Type or Cash-Flow Personal Income Tax, 87 HARV. L. REV. $1113,1123-26$ (1974). The equivalence result assumes that the tax rate is the same when the contribution is made and when the account is liquidated. 
both the income earned on the ESOP's assets and the interest paid on the ESOP loan. ${ }^{97}$ In other words, the interest paid by the employee on the ESOP loan is not deductible. That, in turn, implies that the tax benefit of an ESOP is that the net return for the duration of the ESOP on the funds contributed to through the ESOP escapes tax. .8

\section{A Fairly Simple Example of the Tax Benefits of Using an S ESOP}

The tax advantage from using an S ESOP can be illustrated using the example from Part III. ${ }^{99}$ Although E Corp.'S ESOP holds 100 shares, the interests of the ESOP participants in their employer's securities is not the same as if they held 100 shares on personal account. Since the participants pay tax at ordinary income tax rates on any assets withdrawn from the ESOP, the government in effect owns 35 percent of the assets in the ESOP. Because the only assets in the ESOP are 100 shares of the employer's stock, the government's claim is, in effect, a claim to thirty-five shares. Thus, the S ESOP participants are the economic owners of sixty-five shares of their employer's stock. Moreover, the participants are entitled to receive their sixty-five shares free of taxes and with a basis equal to their fair market value when they withdraw their shares-or an equivalent amount of cash-from the ESOP. ${ }^{100}$ Thus, any appreciation on those sixty-five shares that occurs while they are within the ESOP is never taxed.

It follows from above that the tax benefit to the participants from using an ESOP (rather than holding their shares directly) depends upon how the participants would be taxed if they held their shares directly. There are two polar cases to consider. The tax burden on direct ownership of the $\mathrm{S}$ corporation is generally at its lowest when the income is deferred and taxed as capital gain upon sale (case 1). The tax burden on direct ownership is

${ }^{97}$ Between contributions, the employee's account balance is reduced by interest accruing on the ESOP loan.

98 The interest on the ESOP loan is also not deductible when the loan is viewed from the employer's perspective. With an ESOP, the employer deducts its contributions to the ESOP when they are made. Those payments pay principal and interest. Deferring the employer's deduction until payment is equivalent to providing the employer with an upfront deduction for its contribution (principal) and not allowing a subsequent deduction for the increased contribution (interest).

99 This simple example does not take into account the disadvantage from borrowing through an ESOP. That disadvantage is introduced later in Part IV.B, infra.

100 An S ESOP will usually distribute cash, not employer securities, because the sale of any stock of an S corporation to a disqualified person will disqualify the corporation's $S$ election and subject the corporation to corporate tax. See I.R.C. $\S 1361$ (b)(1) (setting forth requirements to be an $S$ corporation). 
generally at its highest when the income is taxed currently as ordinary income (case 2). ${ }^{101}$

\section{Income from Direct Ownership is Deferred Capital Gain (Case 1)}

Assume that all of the income from direct ownership would be deferred and taxed at 15 percent as long-term capital gain upon sale. ${ }^{102}$ In order to evaluate the tax consequences of the S ESOP structure, consider an otherwise similar group of employees who do not participate in the ESOP, but instead acquire an economically equivalent interest directly. ${ }^{103}$ Accordingly, in order to have the same exposure to their employer's stock as do the ESOP participants, the nonparticipants would have to purchase 76.47 shares at a cost of $\$ 764.71 . .^{104}$ The nonparticipants do not have to purchase as many shares as are in the ESOP- 100 shares-because they will receive 85 percent, instead of only 65 percent, on any subsequent appreciation or depreciation. ${ }^{105}$ In order to pay for their shares, assume that the nonparticipants borrow $\$ 764.71$.

Because the nonparticipating employees do not benefit from contributions to the ESOP, they will receive additional salary of $\$ 162.75$ a year for ten years. The present value of that salary (discounted at 10 percent) is $\$ 1000$. Because the salary is taxable at 35 percent, the nonparticipants will pay $\$ 350$ in taxes, leaving them with $\$ 650$. In other words, the additional salary payments to the nonparticipants are sufficient after tax to pay the principal and interest on a $\$ 650$ loan. ${ }^{106}$ I call that $\$ 650$ loan the "base loan."

101 It is possible for a corporation to generate large amounts of income for several years followed by a large capital loss. In such circumstances, the tax burden on direct ownership exceeds the statutory tax rate. I ignore such possibilities below.

102 I.R.C. $\S 1222$ (2006).

103 In order to qualify as an ESOP, the trust must cover most employees. See I.R.C. $\S \S 401$ (a)(3), 410 (2006). I use the possibility of nonparticipants synthesizing an interest in the ESOP as a heuristic device in order to describe the tax impact of using an S ESOP. In such a comparison, I ignore any difference in the vesting of shares over time.

104 Thus, in order to have the same exposure as holding sixty-five shares that are untaxed, an investor who will be taxed at the 15 percent capital gains rate must purchase $76.47(65 /(1-.15))$ shares. At a price of $\$ 10$ a share, the total cost of such a purchase is $\$ 764.71$.

105 See I.R.C. $\$ \S 1221,1222$.

106 The calculations in the text assume that the interest on the loan to the nonparticipating employee is not tax deductible. That assumption takes out the possibility of tax arbitrage by borrowing and investing in a tax-advantaged investment. If allowance were made for such a possibility, then the tax advantage from using an S ESOP would be smaller (and possibly a disadvantage). See discussion infra note 122 and accompanying text. 
The base loan covers the cost of acquiring the after-tax shares held by the participating employees. Thus, the nonparticipants' total loan exceeds the base loan by $\$ 114.71$. I call that difference the "incremental loan." Thus, the nonparticipating employees will have to pay $\$ 114.71$ plus accrued interest when they sell their shares (which is assumed to occur on the same date as the participating employees withdraw and sell their shares) ${ }^{107}$ In terms of the example, the ESOP loan is $\$ 1000$, the nonparticipant's base loan is $\$ 650$, their incremental loan is $\$ 114.71$, and so the nonparticipants' total loan is $\$ 764.71$

Unlike the participating employees, the nonparticipating employees have basis in their shares. Their aggregate basis is $\$ 764.71$. Because that basis offsets capital gain, which is otherwise taxable at 15 percent, that basis provides a tax savings of exactly $\$ 114.71 .108$ Thus, the nonparticipating employees' tax savings from their basis in their shares will exactly pay off the principal on the incremental loan. However, the nonparticipating employees also have to pay interest on that loan. In the example, interest accrues at 10 percent from the date the ESOP is established until the shares are withdrawn and sold. The interest on the incremental loan totals $\$ 11.47$ in the first year ${ }^{109}$ and increases by 10 percent each year. ${ }^{110}$

\section{Income from Ownership is Taxed Currently as Ordinary Income (Case 2)}

The second polar case assumes that direct ownership would generate only current ordinary income. In that case, the nonparticipating employees would have to acquire 100 shares in order to have the same exposure as participating employees with 100 shares in the S ESOP. The nonparticipants need to purchase 100 shares because all of their income is ordinary-taxed at 35 percent-and so holding 100 shares leaves the nonparticipants with an after-tax return equal to the before-tax return on 100 shares held through an

107 The nonparticipating employees will sell 76.47 shares. Thus, every dollar increase in the stock price will generate an additional $\$ 76.47$. Because that gain is taxed as long-term capital gain at the 15 percent tax rate, the employees will pay $\$ 11.47$ in tax for each dollar increase. Thus, the nonparticipating employees will receive $\$ 65$ for every dollar increase in stock price, as do the participating employees.

108 That is to say, 15 percent of $\$ 764.71$ is $\$ 114.71$.

109 If the interest is tax deductible, then the after-tax cost is 6.5 percent a year; if not, that cost is 10 percent a year. The possibility of deducting interest on the loan outside of the ESOP is discussed below. See infra Part IV.D.3.

110 The situation here is analogous to the decision whether to make the I.R.C. $\S 83(\mathrm{~b})$ election for restricted stock. The ESOP is equivalent to the treatment of restricted stock under I.R.C. $\S 83(\mathrm{a})$. The alternative structure is equivalent to the treatment after making the I.R.C. $\S 83(\mathrm{~b})$ election. 
ESOP. The cost of such shares is $\$ 1000 .^{111}$ As above, the salary will cover principal and interest on the base loan, which covers the cost of purchasing 65 shares. ${ }^{112}$ Thus, to match the participants' exposure, the nonparticipants must purchase an additional 35 shares for $\$ 350$. When the nonparticipants sell their stock and repay the incremental loan, they will pay $\$ 350$ principal on that loan. The nonparticipating employees also have $\$ 1000$ basis, which translates into a tax savings of $\$ 350$. That tax savings pays off the principal on the incremental loan. Thus, one cost of direct ownership in an S corporation, rather than ownership through that corporation'S ESOP, is the after-tax interest paid by the nonparticipant on the incremental loan- $\$ 350$ in the example.

When the $\mathrm{S}$ corporation produces current ordinary income, direct ownership has a second tax cost. Because the $\mathrm{S}$ corporation produces current income-as opposed to deferred income-the holder of a direct interest has to pay taxes as the $\mathrm{S}$ corporation earns income. In contrast, the holder of an interest through an ESOP can defer tax on that income generated by an $\mathrm{S}$ corporation. The advantage of such deferral is that the interest on the income generated by the $\mathrm{S}$ corporation can be reinvested and allowed to compound before paying the tax on that income. Thus, the funds that a direct owner would otherwise use to pay tax can be reinvested to generate income, some portion of which the taxpayer will keep. It is the interest that the ESOP participant earns and keeps on the funds that the nonparticipant would otherwise use to pay taxes that is the second cost of direct ownership.

\section{Estimating the Tax Benefits of Using S ESOPs}

In this section, I generalize the above results. This exercise will allow the reader to estimate the tax benefits to the participants from using an S ESOP instead of making a direct investment in an $\mathrm{S}$ corporation. Denote the personal tax rate by $t_{p}$, the capital gains tax rate by $t_{c g}$, the annual risk-free interest rate by $r$, and the time from establishment and funding of the ESOP until the assets are withdrawn and taxed by $n$. Also, denote the purchase price of the employer's stock at the date the ESOP is established by $P_{0}$.

111 Thus, to get the same exposure as holding 100 shares that are untaxed, an investor who will be taxed at the 35 percent ordinary income tax rate purchases 100 (65/ $(1-.35)$ ) shares. At a price of $\$ 10$ a share, the total cost is $\$ 1000$.

112 Once again, that calculation assumes that the interest on the loan to the nonparticipating employee is not deductible. 


\section{Income from Direct Ownership is Deferred Capital Gain (Case 1)}

In this section, I derive a formula for the cost to an employee of holding one share of the employer's stock directly, rather than holding an equivalent economic interest through an S ESOP. I show that the effect of holding one share of the $\mathrm{S}$ corporation directly rather than indirectly through an S ESOP is that the direct investor is, in effect, tying up $\left[\left(1-t_{p}\right) t_{c g} /\left(1-t_{c g}\right)\right] P_{0}$ dollars for each share held in the S ESOP.

The derivation starts with the observation that an employee who holds one share of her employer's stock directly does not have the same exposure to her employer's stock as an employee who holds one share through an $\mathrm{S}$ ESOP. The former gains $\$\left(1-t_{c g}\right)$ for every dollar increase in price, whereas the latter gains $\$\left(1-t_{p}\right)$. Thus, holding one share directly rather than through an S ESOP increases the holder's economic exposure to her employer's stock by $\left(t_{p}-t_{c g}\right)$ shares from $\left(1-t_{p}\right)$ shares to $\left(1-t_{c g}\right)$ shares. Accordingly, in order for a direct holder to have the same exposure as a holder of one share through an S ESOP, the direct holder must hold $\left(1-t_{p}\right)$ / $\left(1-t_{c g}\right)$ shares.

The holder of shares through an S ESOP is assumed to finance her purchase using an ESOP loan. The loan, in turn, is paid off through contributions by the employer. Assume that the nonparticipating employee borrows on personal account to acquire her shares. Of course, if the employee does not participate in the ESOP, there is no reason for the employer to make contributions to the ESOP on her behalf. Instead, assume the equivalent amount is paid directly to the employee as salary. After paying taxes, the additional salary can carry and repay the base loan-the cost of purchasing $\left(1-t_{p}\right)$ shares. ${ }^{113}$ It, therefore, follows that the incremental loan covers the cost of acquiring $\left(1-t_{p}\right) t_{c g} /\left(1-t_{c g}\right)$ shares. That additional loan puts the direct investor and the ESOP participant on the same cash flow footing at the beginning of the transaction. By comparing the cash flow when the ESOP participant withdraws and sells stock to the cash flow when the nonparticipant sells stock, 114 it is possible to compare the two alternatives. Because the additional basis that the direct holder has from acquiring $\left(1-t_{p}\right)$ $/\left(1-t_{c g}\right)$ shares on personal account is worth $\left[\left(1-t_{p}\right) t_{c g} /\left(1-t_{c g}\right)\right] P_{o}$ when the shares are sold, that saving will exactly pay off the principal of the direct stockholder's incremental loan (the loan to acquire the additional $\left(1-t_{p}\right) t_{c g} /$

113 That assumes that interest on the nonparticipating employee's loan is never deducted. Alternatively, it assumes that the nonparticipating employee would earn taxable interest on those funds if she did not use them to buy shares of her employer's stock. That is to say, she would otherwise invest those funds through a qualified account.

114 I assume that the nonparticipant sells the stock on the same day that the participant withdraws cash from the ESOP. 
(1- $t_{c g}$ ) shares not covered by the base loan). Thus, the tax benefit to the participant from using an S ESOP instead of directly holding shares in the $\mathrm{S}$ corporation is the after-tax interest that the direct holder would pay on the incremental loan. If we denote the accrued interest on $\$ 1$ over the ESOP term by $(1+r)^{n}-1$, then the tax benefit from using the S ESOP is $\left[\left(1-t_{p}\right) t_{c g} /(1-\right.$ $\left.\left.t_{c g}\right)\right] P_{0}\left[(1+r)^{n}-1\right]$. Reducing that amount to a present value at the time the $S$ ESOP is funded ${ }^{115}$ implies that the tax benefit to a participant from using an S ESOP compared with holding shares in the $S$ corporation directly and being paid additional taxable salary, $B$, can be written as follows:

$$
B=\left(\frac{\left(1-t_{p}\right) t_{c g}}{1-t_{c g}}\right) P_{0}\left(1-\frac{1}{(1+r)^{n}}\right)
$$

It follows from equation (1) that the holder is better off with an S ESOP whenever tax rates are positive and the interest rate is positive. Moreover, that benefit will increase as the holding period increases. ${ }^{116}$

Most of the terms in equation (1) are already known. The personal $\left(t_{p}\right)$ and capital gains $\left(t_{c g}\right)$ tax rates are 35 percent and 15 percent, respectively. I use an annual before-tax interest rate of 3.7 percent for the calculations. ${ }^{117}$ Thus, the present values of the tax saving from using an S ESOP, expressed both in dollars for a $\$ 1000$ grant and as a percent of the total grant, are given in Table 2.

115 The present value as of the beginning of the ESOP of one dollar to be received at the end of the ESOP with certainty is $\$\left[1 /(1+r)^{n}\right]$.

116 That is because $r /(1+r)^{n}$ increases with the time to withdrawal $(n)$.

${ }^{117}$ I chose a low-risk, one-year interest rate in the range between the higher rates prevailing in the middle of 2007 , when the Tribune deal was announced, and the lower rates prevailing in the middle of 2008 , when a working version of this Article was posted on SSRN. 
Table 2: Tax Benefit of Using an S ESOP Over Direct Ownership (Assumes Income from Direct Ownership is Deferred Capital Gain) (As a function of time to withdrawal from the ESOP)

\begin{tabular}{|c|c|c|c|c|c|}
\hline Years & 1 & 2 & 3 & 4 & 5 \\
\hline \% Grant & $0.41 \%$ & $0.80 \%$ & $1.18 \%$ & $1.55 \%$ & $1.91 \%$ \\
\hline Dollars & $\$ 4.09$ & $\$ 8.04$ & $\$ 11.85$ & $\$ 15.52$ & $\$ 19.05$ \\
\hline \multicolumn{5}{|l|}{} \\
\hline Years & 6 & 7 & 8 & 9 & 10 \\
\hline$\%$ Grant & $2.25 \%$ & $2.58 \%$ & $2.89 \%$ & $3.20 \%$ & $3.49 \%$ \\
\hline Dollars & $\$ 22.47$ & $\$ 25.76$ & $\$ 28.93$ & $\$ 31.99$ & $\$ 34.94$ \\
\hline \multicolumn{5}{|l|}{} \\
\hline Years & 12 & 15 & 20 & 25 & 30 \\
\hline \% Grant & $4.05 \%$ & $4.82 \%$ & $5.92 \%$ & $6.85 \%$ & $7.61 \%$ \\
\hline Dollars & $\$ 40.53$ & $\$ 48.19$ & $\$ 59.24$ & $\$ 68.46$ & $\$ 76.14$ \\
\hline
\end{tabular}

The entries in Table 2 represent the tax saving from using an S ESOP over direct ownership in the $\mathrm{S}$ corporation. Those numbers can also be used to estimate the increase in an acquirer's possible bid price that is a result of the tax benefits of using an S ESOP. In the case of a firm that is 100 percent owned by an SESOP, the numbers in Table 2 represent the percentage increase in possible bid price. ${ }^{118}$ For lesser ownership amounts, the benefit is roughly the product of the share of the company held through the ESOP and the relevant value in Table 2.119

\section{Income from Direct Ownership is Current Ordinary Income} (Case 2)

When the income from direct ownership is taxed currently and at ordinary income tax rates, the effect of holding shares in the S corporation directly rather than through the S ESOP is equivalent to tying up $t_{p}$ shares of capital for every share held. That is because holding one share directly has the same exposure as holding one share through an S ESOP. Accordingly, the nonparticipating employees must hold as many shares as the ESOP

118 The calculation assumes that the same parties will own the company either directly or through the S ESOP or, alternatively, that any holders through the S ESOP value their interests on the same terms as do outside investors. If the S ESOP holders are reluctant participants, then the comparison cannot be made.

119 I use the qualifier "roughly" because increases in purchase price result in increases in basis, which in turn might generate a tax shield that has value to direct holders. 
participants. Thus, the nonparticipating employees must borrow as much as the ESOP borrows in order to acquire their shares. Their additional salary, after tax, will pay interest and principal on the base loan, which covers the cost of $\left(1-t_{p}\right)$ shares. Also, the nonparticipating employees' basis in their shares will save them $t_{p} P_{0}$, which will pay the principal on the incremental loan. Hence, the first tax benefit from using an S ESOP is that the ESOP participants avoid paying the after-tax interest that the nonparticipating employees pay on the incremental loan.

As described above, the second tax benefit from holding an interest in an $\mathrm{S}$ corporation through an ESOP when the business generates current income is that the holder can reinvest the income generated by the corporation without first having to pay tax on that income. The advantage of such deferral is that the interest can be reinvested at the before-tax interest rate instead of the after-tax interest rate. Assuming that the business generates income at a constant rate, the benefit from using an S ESOP, $B$, can be written as:

$$
B=t_{p} P_{0}\left(1-\frac{1}{(1+r)^{n}}\right)+\left(1-t_{p}\right) P_{0}\left\{\left[(1+r)^{n-1}-1\right]-\frac{\left[\left(1+r\left(1-t_{p}\right)\right)^{n-1}-1\right]}{1-t_{p}}\right\}
$$

The first term in equation (2) is the effect of tying up capital in the incremental loan. The second-complicated and lengthy-term is the difference between compounding interest on the after-tax income generated by the $\mathrm{S}$ corporation at a before-tax interest rate and at an after-tax interest rate.

Substituting values for the various terms in equation (2), the present value from using an SESOP, rather than directly owning shares in the $\mathrm{S}$ ESOP, is given in Table 3. 
Table 3: Tax Benefit from Using an S ESOP over Direct Ownership (As a function of time to withdrawal from the ESOP) (Assumes income from direct ownership is current ordinary income) Before-tax Interest Rate of 3.7 percent

\begin{tabular}{|c|c|c|c|c|c|}
\hline Years & 1 & 2 & 3 & 4 & 5 \\
\hline \% Grant & $1.25 \%$ & $2.45 \%$ & $3.64 \%$ & $4.82 \%$ & $5.98 \%$ \\
\hline Dollars & $\$ 12.49$ & $\$ 24.53$ & $\$ 36.42$ & $\$ 48.17$ & $\$ 59.76$ \\
\hline \multicolumn{5}{|c|}{} \\
\hline Years & 6 & 7 & 8 & 9 & 10 \\
\hline$\%$ Grant & $7.12 \%$ & $8.25 \%$ & $9.37 \%$ & $10.47 \%$ & $11.56 \%$ \\
\hline Dollars & $\$ 71.21$ & $\$ 82.52$ & $\$ 93.69$ & $\$ 104.72$ & $\$ 115.61$ \\
\hline \multicolumn{5}{|l|}{} \\
\hline Years & 12 & 15 & 20 & 25 & 30 \\
\hline$\%$ Grant & $13.7 \%$ & $16.81 \%$ & $21.73 \%$ & $26.36 \%$ & $30.7 \%$ \\
\hline Dollars & $\$ 136.99$ & $\$ 168.06$ & $\$ 217.31$ & $\$ 263.56$ & $\$ 307.00$ \\
\hline
\end{tabular}

The entries in Table 3 are everywhere larger than those in Table 2. That is not surprising. The tax advantage from using an ESOP is greater if the income generated by the $\mathrm{S}$ corporation would otherwise be taxed currently as ordinary income rather than deferred and taxed as capital gain.

\section{Interest Paid on Loan Outside of the ESOP is Tax-Deductible}

The above calculations for the tax benefits of using a leveraged S ESOP assumed that the nonparticipating employee who synthesized the participating employee'S ESOP position by purchasing shares and borrowing on personal account would not be able to deduct her interest payments. That assumption has some basis in the law-interest on personal loans is not deductible. ${ }^{120}$ However, my main reason for making that assumption is to mirror the tax treatment of the ESOP loan. As described above, an ESOP is a tax-efficient investment vehicle because the income earned on assets held in an ESOP is exempt from tax as long as the assets remain within the ESOP. It is precisely what makes an ESOP an attractive investment vehicle that also makes an ESOP an unattractive borrowing vehicle. Interest paid on a loan incurred through an ESOP is, in effect, not deductible by the borrower.

That observation turns the standard (albeit faulty) logic - that an ESOP is attractive from a tax standpoint because principal payments can be deducted - on its head. It suggests that a leveraged ESOP can be an unattractive borrowing vehicle. An ESOP participant who can borrow on personal account on the same terms as the ESOP and receive a deduction

120 I.R.C. $\S 163(\mathrm{~h})(2)(2007)$. 
against ordinary income is better off borrowing on personal account. Such a taxpayer gets the best of both systems-investing through an ESOP (or other qualified account) and borrowing on personal account. ${ }^{121}$ In some circumstances, there are anti-arbitrage provisions that are intended to penalize similar strategies. ${ }^{122}$ The well-known problem with such rules is that money is fungible, which makes them difficult to enforce. ${ }^{123}$ However, even if it is not possible to borrow on personal account and invest through a qualified account, it might still be possible to borrow in a manner that generates tax-deductible interest and to hold the asset directly. In that case, the decision to use a leveraged ESOP involves a trade-off between the tax advantage of avoiding tax on the income generated by the assets in the ESOP and the tax disadvantage of losing the interest deduction on the ESOP loan.

Accordingly, in this section, I have calculated the tax benefits from using an S ESOP assuming that interest paid on the non-ESOP loan would be deductible. That calculation takes place in two steps. In the first, I recalculate the tax benefits from an S ESOP over direct ownership assuming that the interest from the incremental loan (the amount by which the loan without an ESOP exceeds the loan on the participating employee's after-tax portion of the stock with the ESOP) is deductible. ${ }^{124}$ Those calculations, which are made using equation (1) when the $\mathrm{S}$ corporation would produce only deferred long-term capital gain and equation (2) when it would produce only current ordinary income, assume that only the interest on the incremental loan is deductible. Accordingly, in the second step, I calculate the additional tax savings assuming that the interest on the base loan-which covers the cost of acquiring 65 percent of the shares in the ESOP-is also deductible. Subtracting the second number from the first gives the tax advantage from using an SESOP assuming all interest paid outside of the ESOP is tax deductible.

After paying taxes at 35 percent, a before-tax interest rate of 3.7 percent is equivalent to an after-tax interest rate of 2.4 percent. Thus, the after-tax borrowing cost to a nonparticipating employee is 2.4 percent. Setting $r$ in equation (1) equal to 2.4 percent gives the present value of the tax advantage from the SESOP assuming that all of the income produced by the $S$ corporation is deferred long-term capital gain and the interest on the

${ }^{121}$ Tax-deductible interest includes business interest, investment interest, and home acquisition interest.

122 See I.R.C. $\$ 264$ (a) (2007) (denying a deduction on loans incurred to pay some insurance premiums); I.R.C. $\S 265$ (a) (2007) (denying a deduction for interest incurred to buy or acquire tax-exempt securities).

123 The tracing rules are contained in Treas. Reg. $\$ 1.163-8 T$ (a) (1997).

124 That recalculation is required not because the tax treatment of the ESOP has changed-it has not-but because the tax treatment of the counterfactual has changed. 
incremental loan -an additional 11.47 percent of shares in the ESOP-is tax deductible. The results of such an exercise, which recalculates the entries in Table 2 assuming interest on the incremental loan is tax-deductible, are given in Table 2A.

Table 2A: Tax Benefit from Using an S ESOP over Direct Ownership (As a function of time to withdrawal from the ESOP) (Assumes income from direct ownership is deferred capital gain)

\begin{tabular}{|c|c|c|c|c|c|}
\hline Years & 1 & 2 & 3 & 4 & 5 \\
\hline \% Grant & $0.27 \%$ & $0.53 \%$ & $0.79 \%$ & $1.04 \%$ & $1.28 \%$ \\
\hline Dollars & $\$ 2.69$ & $\$ 5.31$ & $\$ 7.88$ & $\$ 10.38$ & $\$ 12.83$ \\
\hline \multicolumn{5}{|c|}{} \\
\hline Years & 6 & 7 & 8 & 9 & 10 \\
\hline$\%$ Grant & $1.52 \%$ & $1.75 \%$ & $1.98 \%$ & $2.2 \%$ & $2.42 \%$ \\
\hline Dollars & $\$ 15.21$ & $\$ 17.55$ & $\$ 19.82$ & $\$ 22.05$ & $\$ 24.22$ \\
\hline \multicolumn{5}{|c|}{} \\
\hline Years & 12 & 15 & 20 & 25 & 30 \\
\hline \% Grant & $2.84 \%$ & $3.43 \%$ & $4.33 \%$ & $5.13 \%$ & $5.84 \%$ \\
\hline Dollars & $\$ 28.41$ & $\$ 34.34$ & $\$ 43.32$ & $\$ 51.31$ & $\$ 58.40$ \\
\hline
\end{tabular}

Not surprisingly, as a quick comparison of Tables 2 and $2 \mathrm{~A}$ illustrates, the tax benefit of using an SESOP is smaller when interest on the incremental loan is otherwise tax-deductible.

Similarly, equation (2) gives the tax benefit from using an S ESOP when all of the income produced by the $\mathrm{S}$ corporation is current ordinary income. Setting $r$ in that equation equal to 2.4 percent gives the present value of the tax advantage from the S ESOP assuming that the interest on the incremental loan-an additional 35 percent of shares in the ESOP-is tax deductible. The results, which recalculate the entries in Table 3 assuming interest on the incremental loan is tax-deductible, are given in Table 3A. 
Table 3A: Tax Benefit from Using an S ESOP over Direct Ownership (As a function of time to withdrawal from the ESOP) (Assumes income from direct ownership is current ordinary income)

\begin{tabular}{|c|c|c|c|c|c|}
\hline Years & 1 & 2 & 3 & 4 & 5 \\
\hline$\%$ Grant & $0.81 \%$ & $1.58 \%$ & $2.35 \%$ & $3.1 \%$ & $3.84 \%$ \\
\hline Dollars & $\$ 8.12$ & $\$ 15.84$ & $\$ 23.47$ & $\$ 31.01$ & $\$ 38.45$ \\
\hline \multicolumn{5}{|c|}{} \\
\hline Years & 6 & 7 & 8 & 9 & 10 \\
\hline$\%$ Grant & $4.58 \%$ & $5.31 \%$ & $6.02 \%$ & $6.73 \%$ & $7.43 \%$ \\
\hline Dollars & $\$ 45.80$ & $\$ 53.05$ & $\$ 60.22$ & $\$ 67.29$ & $\$ 74.28$ \\
\hline \multicolumn{5}{|c|}{} \\
\hline Years & 12 & 15 & 20 & 25 & 30 \\
\hline$\%$ Grant & $8.8 \%$ & $10.79 \%$ & $13.95 \%$ & $16.92 \%$ & $19.71 \%$ \\
\hline Dollars & $\$ 87.99$ & $\$ 107.93$ & $\$ 139.53$ & $\$ 169.20$ & $\$ 197.07$ \\
\hline
\end{tabular}

Once again, a quick comparison of Tables 3 and $3 \mathrm{~A}$ demonstrates that the benefit of using an S ESOP is smaller when interest on the incremental loan would otherwise be tax-deductible.

Tables $2 \mathrm{~A}$ and $3 \mathrm{~A}$ give the tax advantage from an S ESOP over direct ownership of the $S$ corporation assuming that the interest on the incremental loan is deductible by the direct owner. Those calculations also assume that the interest on the base loan -65 percent of shares in the S ESOP-is not deductible by the direct owner. I made that assumption when I originally presented the tables so as to keep the same treatment of interest outside of the ESOP as within the ESOP. If, however, the interest on the incremental loan is deductible, presumably the interest on the base loan is deductible as well. In that case, the interest deductions from the base loan further reduce the tax benefit from holding shares through an S ESOP. Table 4A gives the present value of the tax deductions from a self-amortizing loan at 3.7 percent that covers the cost of the base loan - 65 percent of the shares in the ESOP-as a function of the loan term. 
Table 4: Tax Benefit from Borrowing with Deductible Interest Rather than Through an ESOP (As a function of the Loan Term) (Assumes Loan is SelfAmortizing, Constant Payment over Term)

\begin{tabular}{|c|c|c|c|c|c|}
\hline Years & 1 & 2 & 3 & 4 & 5 \\
\hline$\%$ Grant & $1.26 \%$ & $1.89 \%$ & $2.55 \%$ & $3.21 \%$ & $3.88 \%$ \\
\hline Dollars & $\$ 12.62$ & $\$ 18.89$ & $\$ 25.55$ & $\$ 32.12$ & $\$ 38.78$ \\
\hline \multicolumn{5}{|l|}{} \\
\hline Years & 6 & 7 & 8 & 9 & 10 \\
\hline$\%$ Grant & $4.55 \%$ & $5.23 \%$ & $5.92 \%$ & $6.61 \%$ & $7.32 \%$ \\
\hline Dollars & $\$ 45.50$ & $\$ 52.31$ & $\$ 59.19$ & $\$ 66.15$ & $\$ 73.18$ \\
\hline \multicolumn{5}{|l|}{} \\
\hline Years & 12 & 15 & 20 & 25 & 30 \\
\hline$\%$ Grant & $8.37 \%$ & $9.41 \%$ & $10.44 \%$ & $11.05 \%$ & $11.44 \%$ \\
\hline Dollars & $\$ 83.69$ & $\$ 94.14$ & $\$ 104.44$ & $\$ 110.50$ & $\$ 114.42$ \\
\hline
\end{tabular}

Table 4 is not directly comparable to Tables $2 \mathrm{~A}$ and $3 \mathrm{~A}$. The reason is that Tables $2 \mathrm{~A}$ and $3 \mathrm{~A}$ give the value of using an $\mathrm{S}$ ESOP as a function of the time the assets are held in the ESOP. ${ }^{125}$ In contrast, Table 4 gives the cost of borrowing money through an SESOP (using a level-payment loan) as a function of the loan term. The tables cannot simply be compared because the loan term might not be the same as the ESOP term. Thus, to use the tables together, the loan term gives the value from Table 4. That value is then used with the value generated by either Table $2 \mathrm{~A}$ or $3 \mathrm{~A}$ using the ESOP term.

Consider first the case when the $\mathrm{S}$ corporation generates deferred capital gain. When the loan term is ten years, the cost of borrowing through the ESOP is more than 7 percent of the principal amount of the loan. Looking at Table 2A, the benefit of investing through an ESOP for 30 years is less than 6 percent. Thus, a participant is generally better off borrowing and purchasing the shares on personal account when the $\mathrm{S}$ corporation stock generates deferred capital gain and she can borrow on the same terms as the ESOP and deduct her interest.

When the $\mathrm{S}$ corporation generates current ordinary income, the tax benefits from investing through an ESOP are roughly equal to the tax cost of borrowing through the ESOP assuming the loan term equals the time the assets are held in the ESOP. In the example, the difference in value for a tenyear loan and a ten-year ESOP is less than one tenth of one percent. For shorter holding periods, the personal account is more tax efficient; for longer

125 If the funds withdrawn from the ESOP are rolled over into another qualified account, then the proper term to use is the total time that the funds are held in qualified accounts. 
holding periods, the ESOP is more efficient. The amounts, however, are not large unless the ESOP term is much longer than the loan term. ${ }^{126}$

Thus, when interest on a loan outside of the ESOP would be taxdeductible, the tax benefit from using an S ESOP is much less than that given in the prior section. Depending on the term of the ESOP loan, the mix of ordinary income and long-term capital gain produced by the $\mathrm{S}$ corporation, and how long the employees will leave their securities in qualified accounts, there might not be any tax advantage over direct ownership from using an S ESOP.

\section{E. Caveats in the Estimates}

The above calculations generally represent an upper bound for the tax benefit that can be obtained by using an S ESOP instead of direct ownership in an $\mathrm{S}$ corporation. There are various assumptions buried in those calculations. Several of those assumptions deserve attention.

First, the extent to which the S ESOP provides the employee with a tax advantage depends upon whether the SESOP offsets other holdings in qualified accounts. If the S ESOP replaces holdings in another qualified account, then, in general, there is no tax savings. ${ }^{127}$ If, however, the ESOP does not replace other holdings in qualified accounts, but supplements them, then the participant receives a tax benefit. The benefit of expanding a qualified account is not unique to ESOPs. There are generally other qualified accounts that can be used. Moreover, the limits for such accounts are

126 The adjustment in Table 4 raises the obvious question: what do we do if the taxpayer would not otherwise borrow to invest? In that case, do we still use Table 4 ? The adjustment in Table 4 reflects the value of an arbitrage opportunity. By borrowing and deducting interest, an investor can earn an arbitrage profit by investing on the same terms through a tax-advantaged vehicle. The question becomes: Would or could the investor take advantage of this opportunity, which can be done either through tax-advantaged borrowing or by selling fully taxable assets to fund the alternative investment? If the answer is yes, then the adjustment in Table 4 should be made; otherwise, the adjustment should not be made. My guess-and this is only a guess-is that the adjustment is probably appropriate for wealthy and financially sophisticated parties, but not for the vast majority of ESOP participants.

${ }^{127}$ I use the qualifier "in general" because whether there is a tax saving depends on the relative tax efficiency of the displaced investments in the qualified account. For example, if the displaced investments would be taxed at 35 percent, and the ESOP assets would be deferred and taxed at 15 percent, then the S ESOP does not produce a tax benefit, but has a tax cost. That is because it is more efficient to hold the displaced assets in a qualified account than the assets that displaced them. In other words, an ESOP is an efficient vehicle for holding stock of an $\mathrm{S}$ corporation that generates current ordinary income, but it is not as efficient for holding the stock of an $\mathrm{S}$ corporation that generates deferred capital gain. 
generally for total contributions to all such accounts; there are not separate limits for each type of account and hence additive. ${ }^{128}$ Also, most beneficiaries of S ESOPs are likely to have excess capacity in their qualified accounts. Accordingly, the adoption of an S ESOP is unlikely to expand the capacity of qualified accounts, but at most only to expand the use of such accounts. ${ }^{129}$

Second, the calculation of the tax benefit from using an S ESOP assumes that if stock in the $S$ corporation were held directly the S corporation would not produce any tax shelter that flowed through to the holder. To the extent that there is tax shelter passed through to direct holders of shares in the $\mathrm{S}$ corporation, that is a benefit direct holders enjoy, but which indirect holders through an S ESOP do not. When such benefits take the form of tax deferral-generally by accelerating ordinary deductions and recapturing those deductions at ordinary rates - they reduce the relative benefit from an S ESOP, but they cannot surpass it. This is because the S ESOP, as a qualified account, provides the maximum amount of deferral over the period. However, when the tax shelter takes the form of accelerated deductions against ordinary income that are recaptured at a reduced long-term capital gains rate, then it is possible for the benefit of direct ownership to exceed the benefit of using an S ESOP. ${ }^{130}$

Third, the above calculations assume that direct owners can purchase additional shares on personal account. If the S ESOP owns 100 percent of the company, then it would not be possible for a participant to purchase more shares (assuming that the business cannot be scaled up). In that case, it is not possible for participants to synthesize the increased exposure from directly holding the stock by making outside purchases. In such circumstances, it might be more attractive to hold the stock directly rather than through an ESOP because the holder can obtain greater exposure to the company's stock. ${ }^{131}$ That option, however, will be attractive only if the owners expect

${ }^{128}$ Also, the contribution limits for S ESOPs are stricter than the limits for some other qualified accounts inasmuch as dividend payments count towards the limit with $S$ ESOPs, but not with other qualified accounts.

${ }^{129}$ Many S ESOPs own 100 percent of the sponsoring company. Rosen, supra note 76 , at $i$. In such circumstances, all of the company's income is passed through to the ESOP and deferred. No portion of an S corporation 100 percent owned by an ESOP is subject to current taxation. Although such income is not currently taxed, it will be eventually taxed to participants. Once again, there is no benefit if the S ESOP replaces another qualified account. If it does not, then the effect is to expand use of qualified accounts.

${ }^{130} \mathrm{I}$ also assume that the $\mathrm{S}$ corporation does not produce phantom income, which might occur if the inside basis were lower than the outside basis. I also assume that the tax treatment of increases and decreases in income are symmetric.

131 A similar situation occurs with restricted stock. 
their stock price to appreciate at a rate greater than the risk-adjusted rate of return. Thus, an acquirer who thought she was acquiring the corporation at a discount to its actual value, and who expects the resulting excess return to take the form of capital gains, might prefer to hold as much of her interest as possible outside of the ESOP.

A fourth assumption that was used to arrive at the above results is that the holders of direct interests who pay tax at long-term capital-gain tax rates do not die while holding those interests, nor do they contribute those interests to charities. ${ }^{132}$ The calculations assume that such holders pay capital gain tax when they sell their shares. If they never pay that tax, either because they die holding their shares and their heirs receive a step-up in basis, or because they contribute the shares to charity and can avoid the tax, then the tax consequences of direct ownership and ownership through an ESOP are the same. ${ }^{133}$

Fifth, the above calculations assume that the income tax does not capture any portion of the return that compensates for risk. Instead, the calculations assume that only the risk-free rate of return is captured by any tax. This assumption is standard in the academic literature-both legal and economic-but is often met with skepticism by investors and their advisors. ${ }^{134}$ It is also more likely to be true for wealthy and sophisticated investors than for other investors.

Sixth, the calculations assume that the corporation generates the same cash flow whether its shares are held directly or through an S ESOP. ${ }^{135}$ That assumption has the advantage of isolating the tax consequences of using an S ESOP by separating the tax and non-tax consequences of using an S ESOP. The empirical evidence, however, shows that the adoption of an ESOP leads to greater productivity and increased cash flow. ${ }^{136}$

The above discussion suggests that there is little, if anything, unique about the tax benefits afforded to SESOPs and little reason for an $\mathrm{S}$ corporation to adopt an S ESOP solely to obtain tax benefits. Whatever

132 An owner cannot contribute shares in an $S$ corporation to a charity without causing the $\mathrm{S}$ corporation to become a $\mathrm{C}$ corporation. That is because a charity is not a permissible holder of S corporation stock. See I.R.C. $\S 1361(b)(1)$.

133 When the S corporation generates current ordinary income, holding the stock until death or contributing the stock to charity will not avoid tax on any income.

134 See discussion infra nn. 173-79 and accompanying text.

135 Another assumption that is implicit in making the calculations is that the company would not otherwise be a $C$ corporation, or if it were it would not pay a substantial amount of tax.

136 The empirical studies regularly find significant and substantial productivity gains when a company adopts an ESOP. See Freeman, supra note 6 (surveying studies of ESOPs). 
benefits the S ESOP structure provides will often be available through other means. Numerous structures provide for pass-through taxation and other qualified accounts provide for exemption of the return earned on the assets in an account while they are in a qualified account. Moreover, when an S ESOP offsets an equally tax-efficient qualified account, there is no net tax benefit from using an S ESOP. And when it does not offset another qualified account, then the effect of establishing an S ESOP is simply to expand the use of such accounts. Also, if the participant could have borrowed on the same terms on personal account and deducted the interest, then any benefit from using an S ESOP is likely to be largely (if not entirely) offset by the additional cost of borrowing through the ESOP.

\section{ZELL'S TRIBUNE TRANSACTION}

In April 2007, the Tribune, a publicly traded C corporation, announced that it had agreed to an $\$ 8.2$ billion buyout offer from a group led by Samuel Zell. ${ }^{137}$ In December 2007, the buyout was completed, leaving the Tribune as the largest 100-percent ESOP-owned S corporation 138 and the fifth-largest majority employee-owned company in the United States. ${ }^{139}$ The transaction is complicated. The description below captures the essential features of that transaction for the discussion that follows.

The acquisition took place in two stages. In the first stage, Zell made a $\$ 250$ million investment in the Tribune, the ESOP borrowed $\$ 250$ million from the Tribune and purchased nine million shares at $\$ 28$ a share, and the Tribune borrowed $\$ 7$ billion and redeemed shares at $\$ 34$ a share. ${ }^{140}$ Thus, the ESOP purchased its shares at a substantial discount to Zell. ${ }^{141}$

137 Until approved by the shareholders, the Tribune's board of directors had an obligation to consider other bids, but if they accepted another offer, Zell would have received a $\$ 25$ million break-up fee. See Seelye \& Siklos, supra note 23 (describing the $\$ 25$ million break-up fee as relatively low).

138 Tribune Deal Closes: Company to Become the Largest 100\% ESOP S-Corp, OWNERS AT WORK, 3 (Winter 2007/2008).

139 NATIONAL CENTER FOR EMPLOYEE OWNERSHIP, THE EMPLOYEE OWNERSHIP 100: AMERICA'S LARGEST MAJORITY EMPLOYEE-OWNED COMPANIES (2007), http://www.nceo.org/library/eo 100.html.

140 McIntyre, supra note 1 , at 8.

141 Zell had planned for the Tribune to sell some assets, such as the Chicago Cubs, before converting the Tribune from a $\mathrm{C}$ corporation to an $\mathrm{S}$ corporation. If assets are sold within ten years after conversion, the gain on those assets is still subject to corporate level tax. However, that tax might be avoided if the assets are sold constructively instead of actually. Robert Willens, Will Tribune Corp. Pay Tax on Asset Divestitures?, BNA DAILY TAX REP., Feb. 7, 2008, at 25. 
In the second stage, the Tribune converted from a $\mathrm{C}$ corporation to an $S$ corporation. ${ }^{142}$ The Tribune then borrowed an additional $\$ 3$ billion, and it acquired all outstanding shares not held by the ESOP, leaving the Tribune as a 100-percent owned S corporation. ${ }^{143}$ The Tribune also redeemed Zell's initial $\$ 250$ million investment. 144 Shortly thereafter, Zell made a $\$ 315$ million investment in the form of a $\$ 225$ million subordinated note and the purchase of a warrant for $\$ 90$ million. ${ }^{145}$ The warrant, which can be exercised anytime within fifteen years of issuance, gives Zell the right to acquire 40 percent of the Tribune from the ESOP. ${ }^{146}$ The exercise price of the warrant starts at $\$ 500$ million and increases by $\$ 10$ million a year until it reaches $\$ 600$ million, where it remains until it expires. ${ }^{147}$

The transaction has many interesting aspects, but from a tax perspective what is most interesting is the warrant. ${ }^{148}$ The warrant allows Zell to acquire a 40-percent interest in the Tribune for between $\$ 500$ million and $\$ 600$ million. ${ }^{149}$ Some press reports suggested that Zell made a very good deal at the expense of the remaining ESOP participants because he obtained the right to purchase 40 percent of the Tribune for less than $\$ 1$ billion. ${ }^{150}$ Those reports, however, ignore the debt on the Tribune, which makes the real

142 McIntyre, supra note 1 , at 9.

$143 \mathrm{Id}$.

144 Id. at 8.

145 Id. at 9.

146 Id. Zell is also chairman of the Tribune. I ignore any interest he has in the ESOP as an employee.

${ }^{147} \mathrm{Id}$. The effective price of any shares acquired by Zell through the warrant is at least $\$ 34$ a share. McIntyre, supra note 1 at 8 .

148 According to one estimate, between 15 and 20 percent of S ESOPs use some form of synthetic equity. Proposed Synthetic Equity Tax, supra note 17, at 3-4 (citing Loren Rodgers, Director of Research for the National Center for Employee Ownership).

${ }^{149}$ McIntyre, supra note 1 , at 8 . There are limits on the percentage interest that anyone can hold of the shares of an S ESOP, either directly or indirectly through a derivative. The Code calls such derivatives synthetic equity and limits ownership to a 50 percent interest. I.R.C. $\S 409(p)$. For a discussion of the $\S 409(p)$ rules on prohibited allocations of securities in S ESOPs, see Kaplan et al., supra note 35, at A-32-A-36; Carolyn F. Zimmerman, Complying With the Section 409(p) Anti-Abuse Rules, in S CORPORATION ESOPS 93 (Scott Rodrick ed., 2d ed. 2005).

${ }^{150}$ E.g., The Conspiracy to Keep You Poor and Stupid, There's Never a Financial Media Around When You Need One, http://www.poorandstupid.com/ (Apr. 6, 2007, 13:28 EST); Jones, supra note 62. 
acquisition cost-and the value of the company at which the warrant becomes worth exercising - much higher than the warrant's exercise price. ${ }^{151}$

From a tax perspective, what is interesting about the warrant is that it is a capital asset in Zell's hands. If Zell held a 40-percent interest in the Tribune directly, then he would be allocated 40 percent of all income that the Tribune earned after payment of expenses, including interest, compensation, and allowances for depreciation and amortization. ${ }^{152}$ Accordingly, if the acquisition was very successful and the Tribune produced large amounts of current ordinary income that it used to pay down the debt, then 40 percent of that income would be allocated to Zell. Moreover, Zell would have to pay tax on that income at the ordinary income tax rate of 35 percent. ${ }^{153}$ Alternatively, if the acquisition did not produce large amounts of current ordinary income, but was still very successful because of the prospect of large future revenues, Zell could then sell his shares for a profit. That profit would be taxed as longterm capital gain, which currently has a top tax rate of 15 percent. ${ }^{154}$ Most likely, if Zell held his interest in the Tribune directly, and if the transaction were a success, he would have a combination of ordinary income and deferred long-term capital gain.

There are, thus, two tax advantages to Zell from holding his Tribune interest as an S ESOP derivative rather than as a direct interest in the $\mathrm{S}$ corporation. First, Zell can dispose of his warrant at any time within its 15year life in a manner that will ensure that his entire gain (assuming that there is a gain) is capital. ${ }^{155}$ If Zell held that interest directly, he would likely have some ordinary income. Thus, the first benefit from the structure is conversion of ordinary income into capital gain. Second, the warrant allows Zell to avoid paying tax on any portion of his gain until he disposes of his interest (assuming he disposes of that interest within fifteen years). ${ }^{156}$ If Zell held that interest directly, he would likely have some income in earlier years. Thus, the second benefit is deferral of taxation.

151 The pricing of the shares to the S ESOP and the terms of the warrant ensure that if Zell exercises his warrant, the participants will earn a higher return than Zell. Oneal \&Rosenthal, supra note 23 .

152 The amortization and depreciation allowances are likely to be small relative to the acquisition price because it is usually optimal to acquire free standing $\mathrm{C}$ corporations, such as the Tribune, using a structure that does not lead to a step up in basis. See Scholes \& Wolfson, supra note 56.

153 See I.R.C. § 1366(a) (pass through of S corporation income to shareholders).

$154 \mathrm{~S}$ corporation stock is a capital asset under I.R.C. $\S 1221$ and so its sale generates capital gain or loss under I.R.C. $\S 1222$.

155 Any losses are also likely to be capital.

156 McIntyre, supra note 1 , at 9. 
Another feature of the warrant is that it will not have adverse tax consequences for the ESOP participants. Their withdrawals, which are after dilution by the warrant (assuming the warrant is exercised), are taxed at ordinary income tax rates. ${ }^{157}$ In effect, the S ESOP blocks the Tribune's tax consequences from being passed through to the participants until they withdraw their assets. ${ }^{158}$ Thus, the tax consequences of the warrant are solely the consequences for Zell: conversion and deferral.

The key tax feature of the warrant is that it is taxed as a capital asset in Zell's hands, not as an ownership interest. ${ }^{159}$ That treatment is not related to the warrant's option element; it would apply as well to a forward contract. ${ }^{160}$ Thus, consider a prepaid forward contract that entitles the holder to receive forty shares at a future date without an additional payment. ${ }^{161}$ The cost of such a forward is $40 P_{0}$. If such a transaction were respected and taxed according to its form, then an ESOP participant would be taxed at the same time as the direct owner assuming that the owner was certain to receive all his income in the form of deferred capital gain. ${ }^{162}$ In order for an ESOP participant to have the same exposure as the forward contract holder, the ESOP must contain 52.3 shares. ${ }^{163}$ The after-tax cost to the ESOP participant of such shares is $34 P_{0}{ }^{164}$ Once again, the cost of the direct or derivative purchase is $6 P_{0}$ more than the after-tax cost of acquiring the economically equivalent position through an ESOP. However, the direct or derivative purchase produces a basis of $40 P_{0}$, which, in turn, produces a tax saving of $6 P_{0}{ }^{165}$ That saving will pay off the principal, but not the interest, on the loan used to purchase the prepaid forward. Thus, the benefit from using an ESOP instead of a derivative contract is the interest paid on the amount of capital (unproductively) tied up by making a direct or derivative purchase instead of

${ }^{157} \mathrm{Id}$.

${ }^{158} \mathrm{Id}$.

159 Id.

160 Options and warrants both meet the definition of a capital asset under I.R.C. $\S 1221$.

161 I assume the stock does not pay dividends.

162 Both would be taxed at 15 percent and so on an after-tax basis would receive the appreciation on thirty-four shares.

163 That is calculated as 34 shares / $(1-.35)$.

164 That is calculated as 52.3 shares $\times(1-.35) \times P_{0}$.

${ }^{165}$ Because all income is capital gain, the basis produces a saving at the 15 percent capital gains rate. 
acquiring the position through an ESOP.166 In other words, the tax consequences of holding a derivative on an S ESOP are not as attractive as those of holding the economically equivalent position through an S ESOP.

More generally, the tax advantage of holding an interest through an $\mathrm{S}$ ESOP rather than through a derivative upon shares in the ESOP is given by equation (1). Accordingly, Table 2 gives the advantage from an S ESOP as a function of how long the assets are held in the ESOP. That advantage does not depend upon whether the income is current ordinary income or deferred capital gain. That is because the ESOP blocks the income from passing through, whether the interest is held through the ESOP or in the form of a derivative on the shares in the ESOP.

Returning to the Tribune transaction, Zell could not have acquired his interest through an ESOP, nor could he have acquired it through another qualified account. ${ }^{167}$ Thus, Zell was left with the choice between holding his interest in the Tribune directly or through an ESOP derivative.

The advantage of the derivative is that it treats all income- whether current and ordinary or deferred and capital-as deferred capital gain. ${ }^{168}$ Accordingly, the two structures yield the same tax result when all of the income is deferred capital gain. If, however, all of the income is current and ordinary, then the tax benefit from the S ESOP structure is given by the difference between equations (2) and (1). In those circumstances, the benefit generated by holding an interest in the form of a derivative on the S ESOP rather than holding shares in the $S$ corporation directly is given by the following equation:

$$
B=\frac{t_{p}-t_{c g}}{1-t_{c g}} P_{0}\left[1-\frac{1}{(1+r)^{n}}\right]+\left(1-t_{p}\right) P_{0}\left\{\left[(1+r)^{n-1}-1\right]-\left[\frac{\left(1+r\left(1-t_{p}\right)\right)^{n-1}-1}{\left(1-t_{p}\right)}\right]\right\}
$$

Equation (3) is an upper bound for the tax benefit of synthetic equity because it assumes all of the income generated by the $S$ corporation would be taxed currently as ordinary income if the shares were held directly.

166 The text assumes that either the direct purchase is funded out of cash that would otherwise be invested in a manner that generates ordinary interest income or the interest paid on any borrowing is not deductible.

${ }^{167}$ In an interview, Zell emphasized that, as chairman, he is also a Tribune employee and holds an interest through the ESOP. See Phil Rosenthal et al., On the Future, Dealmaking and Bad Press, CHI. TRIB., Apr. 4, 2007, at C1. That interest, however, is very small in comparison with his warrant.

168 Tax Reduction and Control Act, H.R. 3970, 110th Cong. § 409B (2007). Section 3701 of H.R. 3970 would add $\S 409 B$ to the Internal Revenue Code. That provision would tax holders of synthetic equity as if they owned the underlying equity directly. 
In Table 5, I use equation (3) to calculate the value of holding shares through an S ESOP derivative over holding such shares directly (assuming interest payments are deductible).

Table 5: Tax Benefit from Using an S ESOP Derivative over Direct Ownership (As a function of time to withdrawal from the ESOP) (Assumes income from direct ownership is current ordinary income)

\begin{tabular}{|c|c|c|c|c|c|}
\hline Years & 1 & 2 & 3 & 4 & 5 \\
\hline$\%$ Grant & $0.84 \%$ & $1.65 \%$ & $2.46 \%$ & $3.27 \%$ & $4.07 \%$ \\
\hline Dollars & $\$ 8.40$ & $\$ 16.49$ & $\$ 24.58$ & $\$ 32.65$ & $\$ 40.71$ \\
\hline \multicolumn{5}{|l|}{} \\
\hline Years & 6 & 7 & 8 & 9 & 10 \\
\hline \% Grant & $4.87 \%$ & $5.68 \%$ & $6.48 \%$ & $7.27 \%$ & $8.07 \%$ \\
\hline Dollars & $\$ 48.75$ & $\$ 56.77$ & $\$ 64.76$ & $\$ 72.73$ & $\$ 80.67$ \\
\hline \multicolumn{5}{|l|}{} \\
\hline Years & 12 & 15 & 20 & 25 & 30 \\
\hline$\%$ Grant & $9.65 \%$ & $11.99 \%$ & $15.81 \%$ & $19.51 \%$ & $23.09 \%$ \\
\hline Dollars & $\$ 96.45$ & $\$ 119.86$ & $\$ 158.07$ & $\$ 195.11$ & $\$ 230.86$ \\
\hline
\end{tabular}

Equation (3) and Table 5 can be used to estimate an upper bound for Zell's tax saving from the structure. The tax saving from the warrant is roughly that of a straight 40-percent interest in the ESOP if held as a derivative. Assume such an interest would be worth $\$ 100$ million. ${ }^{169}$ At most, then, the derivative would save Zell taxes worth 12 percent of the value of his interest, or about $\$ 10$ million. That assumes that the warrant is held for fifteen years before exercise and all of the income from direct ownership takes the form of currently taxed ordinary income earned ratably over the fifteen-year period, plus reinvestment in bonds. Although the tax saving is a large amount of money standing on its own, it is only a small portion-less than one percent- of the total acquisition cost of the Tribune. Thus, the tax advantages of the structure would have allowed Zell to raise his bid for the Tribune by less than one percent.

169 Zell paid $\$ 90$ million for the warrant, presumably market value for that interest. McIntyre, supra note 20, at 1. 
Once again, it is important to recognize the assumptions under which the calculations in Table 5 were made. They include the following:

(i) there is no qualified account available;

(ii) the investor can borrow at the same interest rate as the ESOP and can generate a tax deduction on that borrowing;

(iii) there is effectively no taxation of the return to risk bearing;

(iv) all income is current and ordinary;

(v) the asset does not generate any tax shelter (symmetry of tax treatment); and

(vi) the $\mathrm{S}$ corporation generates the same cash flow with or without an S ESOP 170

The first assumption is reasonable to make for Zell, as is the second. He is very likely to be able to borrow on the same terms as the ESOP and deduct his interest. However, the ESOP will borrow very little - about 3 percent of the Tribune's debt. ${ }^{171}$ Thus, the effect of the assumption that interest on Zell's share of the ESOP loan would be deductible by Zell if he borrowed the money himself is small.

The third assumption, however, is the key. According to Merrill Lynch's projections, the Tribune will generate free cash flow, after accounting for capital spending, of close to $\$ 300$ million in 2008 , rising to over $\$ 500$ million by $2012 .{ }^{172}$ If Zell were the direct owner of a 40 percent stake in the Tribune, and if such cash flow were realized, then 40 percent of that cash flow would be taxable to Zell each year. However, with the S ESOP derivative, Zell is taxed at capital gains rates on that return when he sells his stake. If the Tribune were to generate $\$ 300$ million a year in free cash flow that it used to pay down its debt, then Zell would receive 40 percent of the benefit, or $\$ 120$ million a year. If Zell held his interest directly, that income would be allocated to him for inclusion on his annual tax return. His tax, at a 35 percent tax rate, is $\$ 42$ million a year. Over ten years, say, his tax from the Tribune paying down its debt would total $\$ 420$ million, with a present value of $\$ 345.8$ million. ${ }^{173}$ In contrast with direct ownership, the warrant converts that income into capital gain. Thus, Zell's tax bill from the Tribune paying down $\$ 3$ billion in debt- $\$ 1.2$ billion of which is Zell's share-is $\$ 180$

${ }^{170}$ Another assumption in the calculations is that the company would not otherwise be a $\mathrm{C}$ corporation, or if it were, it would not pay a substantial amount of tax.

171 The ESOP will borrow $\$ 250$ million, which is about three percent of the Tribune's $\$ 8.5$ billion borrowing to complete the transaction. McIntyre, supra note 20 , at 1.

172 Oneal \& Rosenthal, supra note 23.

173 The tax is discounted at the after-tax interest rate of 3.7 percent a year. 
million. Moreover, because Zell pays that tax when he sells the warrant, assumed to be ten years after its acquisition, the present value of that tax is only $\$ 125.2$ million. In such circumstances, the warrant would appear to save Zell \$220 million in taxes over direct ownership.

Yet it is questionable whether there is such a large tax benefit from the structure. The Tribune was sold at auction at a substantial premium. No one has suggested that the total purchase price paid by Zell, which includes the debt assumed, was below the market price. There does not appear to be money left on the table by the Zell group. That suggests that if there is a reasonable expectation of such a cash flow on such a small equity investment it must be because of the high level of risk assumed by Zell. That there is an incremental return to risk-bearing is well documented in the economic literature. ${ }^{174}$ The question is whether the tax system captures that return.

More than sixty years ago, Evsey Domar and Richard Musgrave showed that the income tax does not tax the return to risk-bearing as long as the tax system taxes above and below average returns symmetrically. ${ }^{175}$ In such a case, they show that the taxpayer can eliminate the tax on risk by borrowing and scaling up her investment in the risky asset by $1 /(1-t)$, where $t$ is the tax rate on incremental gains and losses. 176

The Domar-Musgrave result has been the source of a large and growing literature. ${ }^{177}$ Although there are some questions as to how well the result holds in the economy at large, there is generally a consensus that sophisticated and wealthy taxpayers can and do make the adjustments that eliminate the tax on the risk premium. ${ }^{178}$ Zell is certainly a wealthy and sophisticated investor. ${ }^{179} \mathrm{He}$ could offset the tax consequences of the risky element of his derivative ownership of stock by borrowing and increasing

174 See BREALEY ET AL., supra note 31, at 957-58. In the standard capital asset pricing model, the return to risk bearing comes from bearing systematic as opposed to unsystematic risk. See id. at 188-91; STEPHEN A. ROSS ET AL., CORPORATE FINANCE 284 87 (7th ed. 2005).

175 See Evsey D. Domar \& Richard A. Musgrave, Proportional Income Taxation and Risk Taking, 58 Q.J. ECON. 388 (1944).

176 See id.

177 See generally Lawrence Zelanek, The Sometimes Taxation of the Returns to Risk-Bearing Under a Progressive Income Tax, 59 SMU L. REV. 879 (2006).

${ }^{178} \mathrm{Id}$. at 895 . It is irrelevant whether an investor actually makes the adjustment. What matters is that the investor is taxed symmetrically on gains and losses so that such investor could offset the effect of the tax by borrowing and purchasing more of the asset.

${ }^{179}$ I assume that the Tribune's debt is not guaranteed by Zell. Thus, if the Tribune experiences losses, they will only be borne by Zell to the extent of his investment in the Tribune, which is less than 3 percent of the total acquisition cost. If the Tribune performs poorly, most of the loss will be borne by the lenders. Thus, there is no large asymmetry that could cause the Domar-Musgrave result to break down. 
that interest from 40 percent to 61.5 percent. ${ }^{180}$ More simply, instead of borrowing, he could have taken some part in the $\$ 225$ million loan he made to the Tribune and used that money instead to purchase a larger interest in the Tribune. ${ }^{181}$

The point of the exercise above is not the mechanics, but to show that the claim that the SESOP creates substantial value because it defers and converts from ordinary income into capital gain-which is the source of most of the income he expected to receive-the income Zell would receive as compensation for taking on risk is questionable. That is because Zell, through fairly simple adjustments, could have avoided that tax. Thus, the claim that there are substantial tax benefits to Zell from using the S ESOP structure is also questionable.

\section{CONCLUSION}

I think any reader who has followed me this far will agree that the tax consequences of S ESOPs are complex. Understanding those consequences takes more than just reading the law and looking at how one or more transactions are taxed. It requires consideration of the tax treatment of alternative structures and careful separation of the tax and non-tax consequences to all parties of using an S ESOP.

Once alternative structures are considered, the claim that there are substantial and unique tax advantages from using an S ESOP is questionable. The most common argument - that the S ESOP structure allows employers to deduct principal on loan repayments -is mistaken. Deducting repayment of the principal on the ESOP loan is not a source of tax advantage; it is simply the deduction by an employer of compensation paid to an employee in the form of paying off an obligation of the employee.

180 The mechanics of the offsetting transactions are more complicated than in the usual Domar-Musgrave example because tax on the interest held through the ESOP derivative is deferred whereas the tax payments with direct ownership are made over time, not at once. Simplifying, if Zell held 61.5 percent of the Tribune directly, he would benefit from every $\$ 300$ million of free cash flow generated by the Tribune and used to pay down its debt to the extent of $\$ 185$ million. On this amount, he would have to pay $\$ 65$ million in tax, leaving him with a net benefit of $\$ 120$ million. That is calculated as follows: $61.5 \%=40 \% /(1-.35)$. That is the same $\$ 120$ million benefit he would receive if each year the Tribune paid down $\$ 300$ million of its debt as projected by Merrill Lynch.

181 Zell's loan to the Tribune is subordinated to $\$ 8.5$ billion in other loans. In effect, Zell is at risk for the entire equity investment, because his loan funds the ESOP share purchase, but he does not get all of the benefits, because the other ESOP beneficiaries receive 60 percent of the shares and are guaranteed to receive a higher return than is Zell. See McIntyre, supra note 1, at 9. 
However, a second claim - that the S ESOP allows participants to defer their income-is true. In effect, the ESOP exempts the return on the assets contributed to the ESOP over the life of the ESOP. Although the S ESOP structure has that desirable characteristic, it is not unique in providing that benefit. Other structures, most notably other qualified accounts, provide that same benefit. Moreover, because the contribution limits on such accounts are not separate for each type of account, but instead there is a single limit for contributions to all of a beneficiary's qualified accounts together, the use of an S ESOP does not expand access to such accounts; at most it only expands their use.

Accordingly, in many circumstances, there will not be a substantial tax benefit from using an S ESOP. First, if the S ESOP displaces other qualified accounts, the effect is essentially a wash. ${ }^{182}$ Second, if the S ESOP participants can borrow on the same terms as the ESOP and deduct their interest payments, then there is also a cost from using a leveraged S ESOP. The participants, in effect, lose their interest deductions on the loan incurred through the ESOP as compared with borrowing outside of the ESOP and making an upfront contribution to an ESOP or another qualified account. In some circumstances, the tax cost from the lost interest deductions will equal or exceed the tax benefits from holding assets inside of an S ESOP. The tax cost to the owner of borrowing through an S ESOP (relative to the benefits of holding the purchased assets through an S ESOP) is larger the higher the leverage, the longer the duration of the loan relative to the duration of the investment, and the more deferred capital gain and the less current ordinary income the assets produce.

Third, it is unlikely that a sophisticated buyer, such as Zell, would realize a substantial tax benefit from holding a synthetic interest in an S ESOP rather than a direct interest in an $\mathrm{S}$ corporation. That is because he can eliminate the tax he would pay on that portion of his income that is a return for bearing risk with a direct interest in the $\mathrm{S}$ corporation by engaging in offsetting portfolio transactions. ${ }^{183}$

182 The offset, however, will not always be equal even if the S ESOP displaces an equal amount of investment in other qualified accounts. That is because assets that produce current ordinary income are taxed more heavily than those that produce deferred capital gain. Accordingly, the tax benefit from holding the former in a qualified account is greater than the tax benefit from holding the latter. It thus follows that a company that produces a large amount of current ordinary income is a better candidate for an S ESOP than one that produces less current ordinary income and more deferred capital gain.

183 Thus, the tax benefit from holding an interest through an S ESOP derivative rather than directly in an S corporation or other pass through entity is that the holder's ordinary return is taxed as deferred long-term capital gain. To the extent that a direct interest will produce ordinary income instead of long-term capital gain or accelerate income, there is a tax benefit from using an S ESOP derivative. However, that tax benefit 
At the end of the day, there can be a tax benefit from use of the S ESOP structure (with or without synthetic equity) rather than from direct ownership, but often there will be little, if any tax benefit from using an $\mathrm{S}$ ESOP relative to the tax benefits that can be achieved from using other feasible and readily available structures. Moreover, when there are tax benefits from using an S ESOP, most of those benefits will likely accrue to the smaller, less sophisticated investors at whom those benefits are targeted, and they will not be any greater than the benefits those same investors would achieve from expanding the use of qualified accounts.

In December 2007, Zell purchased the Tribune using a novel S ESOP structure. That structure appeared to offer various tax benefits, which led many sophisticated commentators to opine that the S ESOP structure was the wave of the future. ${ }^{184}$ However, as the analysis above shows, although Zell might have achieved some tax benefits to Zell from using an S ESOP that he could not have achieved with another structure, any such benefits were very small relative to the size of the transaction. Thus, the S ESOP structure should not have permitted Zell to pay substantially more for the Tribune and is unlikely to enable future bidders to pay substantially more for other target companies.

It is, of course, a separate question whether the appearance of connecting large amounts of ordinary income into long-term capital gain and deferring tax on that gain led Zell and his advisors to believe there would be large tax benefits from the S ESOP structure and hence induced him to raise his bid accordingly. However, as this Article shows, the appearance of those benefits was only an appearance. There were no large tax advantages from the structure.

is only on that portion of the ordinary return on the equity investment that the derivative defers or recharacterizes.

184 See note 24, supra, and accompanying text. 
